\title{
9. MINERALOGIC VARIATIONS IN A PLEISTOCENE HIGH-RESOLUTION EOLIAN RECORD FROM THE OWEN RIDGE, WESTERN ARABIAN SEA (SITE 722): IMPLICATIONS FOR SEDIMENT SOURCE CONDITIONS AND MONSOON HISTORY ${ }^{1}$
}

\author{
L. A. Krissek ${ }^{2}$ and S. C. Clemens ${ }^{3}$
}

\begin{abstract}
Bulk mineralogy of the terrigenous fraction of 99 samples from ODP Site 722 on the Owen Ridge, western Arabian Sea, has been determined by $x$-ray diffraction, using an internal standard method. The sampling interval, approximately 4.3 k.y., provides a detailed mineralogic record for the past 500 k.y. Previous studies have identified important modern continental sediment sources and the mineral assemblages presently derived from each. These studies have also demonstrated that most of this material is supplied by southwest and northwest winds during the summer monsoon. A variety of marine and terrestrial records and general circulation model (GCM) simulations have indicated the importance of monsoonal circulation during the Pleistocene and Holocene and have demonstrated increased aridity during glacial times and increased humidity during interglacials. The mineralogic data generated here were used to investigate variations in source area weathering conditions during these environmental changes.

Terrigenous minerals present include smectite, illite, palygorskite, kaolinite, chlorite, quartz, plagioclase feldspar, and dolomite. This mineralogy is consistent with the compositions of source areas presently supplying sediment to the Arabian Sea. An R-mode factor analysis has identified four mineral assemblages present throughout the past $500 \mathrm{k} . \mathrm{y}$ : quartz/chlorite/dolomite (Factor 1), kaolinite/plagioclase/illite (Factor 2), smectite (Factor 3), and palygorskite/dolomite (Factor 4). Chlorite, illite, and palygorskite are extremely susceptible to chemical weathering, and a spectral comparison of these factors with the eolian mass accumulation rate (MAR) record from Hole 722B (an index of dust source area aridity) indicates that Factors 1, 2, and 4 are directly related to changes in aridity. Because of these characteristics, Factors 1, 2, and 4 are interpreted to originate from arid source regions. Factor 3 is interpreted to record more humid source conditions.

Time-series of scores for the four factors are dominated by short-term (10-100 k.y.) variability, and do not correlate well to glacial/interglacial fluctuations in the time domain. These characteristics suggest that local climatic shifts were complex, and that equilibrium weathering assemblages did not develop immediately after climatic change. Spectral analysis of factor scores identifies peaks at or near the primary Milankovitch frequencies for all factors. Factor 1 (quartz/chlorite/dolomite), Factor 2 (kaolinite/plagioclase/illite), and Factor 4 (illite/palygorskite) are coherent and in phase with the MAR record over the 23,41 , and 100 k.y. bands, respectively. The reasons for coherency at single Milankovitch frequencies are not known, but may include differences in the susceptibilities of minerals to varying time scales of weathering and/or preferential development of suitable continental source environments by climatic changes at the various Milankovitch frequencies.
\end{abstract}

\section{INTRODUCTION}

One of the major objectives of drilling in the Arabian Sea during ODP Leg 117 was to recover and investigate the high-resolution pelagic sediment sections deposited on the Owen Ridge under the influence of the Indian Ocean monsoon. The summer monsoon in the Arabian Sea is driven by the combination of two effects: differential heating of southern Asia relative to the Indian Ocean, and direct latent heating of the troposphere over southern Asia resulting from the condensation of water vapor evaporated from the Indian Ocean (Webster, 1987). The passage of strong monsoonal winds over arid continental regions presently supplies significant terrigenous material from several source areas to the northwest Arabian Sea (Sirocko and Sarnthein, 1989; Nair et al., 1989; Savoie et al., 1987; Chester et al., 1985). These eolian contributions carry mineralogically distinct signatures that are observable in surface and subsurface sediments of the Arabian Sea (Sirocko and Sarnthein, 1989; Debrabant et al., this volume; Kolla et al., 1976, 1981).

\footnotetext{
${ }^{1}$ Prell, W. L., Niitsuma, N., et al., 1991. Proc. ODP, Sci. Results, 117: College Station, TX (Ocean Drilling Program).

2 Department of Geology and Mineralogy, Ohio State University, Columbus, OH 43210-1398, U.S.A.

${ }^{3}$ Department of Geological Sciences, Brown University, Providence, RI 02912 1846, U.S.A.
}

Clemens and Prell (this volume; 1990) have demonstrated the eolian origin of the terrigenous fraction of Owen Ridge sediments, and have used the grain size and the mass accumulation rate (MAR) of the terrigenous fraction to monitor southwest (summer) monsoon strength and dust source area aridity over the past $1 \mathrm{~m}$.y. They conclude that variations in the strength of either or both of the two monsoon-forcing mechanisms may be partially responsible for variations in monsoon wind strength over this time interval. Debrabant et al. (this volume) used mineralogic data to demonstrate that eolian material has dominated terrigenous input to the Owen Ridge since its uplift in the middle Miocene. However, the wider sampling interval of the latter study precluded a detailed investigation of Quaternary source areas and changes in their importance over the interval investigated by Clemens and Prell (this volume).

As a result, the objectives of this study are as follows: to develop a detailed mineralogic record of the eolian component of Owen Ridge sediments for the past 500 k.y.; to identify weathering/climatic conditions in continental dust source areas from their mineralogical signatures; and to evaluate the significance of temporal variations in the importance of each assemblage. To our knowledge, this is the first detailed mineralogic study of a high-resolution eolian record. The mineralogic data constrain paleoclimatic interpretations of the eolian component by identifying conditions within the sediment source areas and clarifying temporal relationships between variations in source area conditions and global paleoclimate. 


\section{Background and Previous Work}

General relationships between the lithology and the weathering regime of a continental source area and the composition of the clay mineral assemblage derived from that source area were established on a global scale by Griffin et al. (1968) and Lisitzin (1972). Numerous other studies have confirmed such relationships on basinwide, regional, and local scales. These relationships were used by Kolla et al. (1976) and Kolla et al. (1981) to interpret clay mineral abundance data from surface sediments of the western Indian Ocean and the Arabian Sea. On the basis of modern geographic patterns of clay mineral abundances, they concluded that:

1. Smectites are predominantly derived from the Deccan Traps of India at the present time, enter the Arabian Sea via fluvial discharge, and are transported to the south by surface currents;

2. Illites and chlorites are presently derived from the Himalayan complex, from the arid regions of Iran-Makran, and from alluvial sediments adjacent to the latter region. Sediments derived from the Himalayas are transported to the Arabian Sea by the Indus River, and are generally confined to the Indus Fan; additional material rich in illite and chlorite may be carried from the Thar Desert of India by northeast winds, but could not be distinguished from the Indus signal by Kolla et al. (1981). Sediments derived from the soils of Iran-Makran are transported to the Arabian Sea by northerly and/or northwesterly winds;

3. Palygorskite (a fibrous clay) is presently derived from soils of the Arabian Peninsula and Somalia, and is supplied to the Arabian Sea by westerly and southwesterly winds;

4. Kaolinite is presently derived from tropical soils of Africa, Madagascar, and southern India, but is of minor importance in the northern Arabian Sea.

More recent studies have examined the timing and dynamics of eolian input to the Arabian Sea by analyzing aerosols (Chester et al., 1985), determining seasonal variations in sediment component fluxes (Nair et al., 1989), and comparing a yearlong record of dust trajectories from satellite images to spatial patterns of sediment accumulation rates over the past $8 \mathrm{k} . \mathrm{y}$. (Sirocko and Sarnthein, 1989). Aerosols sampled over the northern Arabian Sea during the northeast monsoon were compositionally similar to the underlying sediments (relatively rich in chlorite), and similar to material derived from the Iran-Makran region (Chester et al., 1985).

Sediment trap data from the western Arabian Sea demonstrate that $80 \%$ of the terrigenous flux occurs during the time of the southwest monsoon (Nair et al., 1989), and originates from eolian transport. Terrigenous fluxes are also enhanced in the central and eastern Arabian Sea during the time of the southwest monsoon, but result from increased discharge of the Indus River. Accumulation rates of various terrigenous components over the past $8 \mathrm{k}$.y. outline a major source in Oman, which supplies chlorite, dolomite, and detrital carbonate via summer northwesterly winds, and a major source in central Arabia, which supplies palygorskite and smectite via a southwestern branch of the summer Arabian northwesterlies (Sirocko and Sarnthein, 1989). Fluxes of these eolian materials compare well with an estimate of transcoastal dust flux derived from satellite images for 1979. Sirocko and Sarnthein (1989) argue that most of this eolian material is not transported by the southwest monsoon, and therefore cannot be used as a marker of monsoon intensity; Clemens and Prell (1990), however, recognize that the summer northwest and southwest wind strengths are coupled by their mutual dependence on the low pressure cell over India, so that eolian sedimentation by either wind system responds to the same largescale climatic boundary conditions.

Climatic fluctuations in these source regions over time scales of thousands of years or more may have affected the mineralogy of sediments derived from each. Street and Grove (1979), van Campo et al. (1982), Prell and van Campo (1986), and van Campo (1986) have documented increased humidity during interglacials and increased aridity during glacials in this area during the Pleistocene. These interpretations agree with the results of paleoclimatic modeling (Kutzbach, 1981; Kutzbach and OttoBliesner, 1982; COHMAP Members, 1988).

The results of van Campo et al. (1982) and Prell and van Campo (1986) are especially important to this study. van Campo et al. (1982) concluded that saline littoral, arid, and steppe inland conditions expanded during the last glacial, accompanied by stronger winter northeast trade winds. Savanna-type vegetation dominated during the humid interglacials, with transport dominated by the summer southwest monsoon. Prell and van Campo (1986) demonstrated the association of strong southwest monsoons and increased precipitation with interglacials, whereas glacial periods were marked by weaker monsoons, perhaps following different trajectories, and more arid conditions.

\section{MATERIALS AND METHODS}

Samples for this study were collected from Hole 722B, which is located on the Owen Ridge at $16^{\circ} 37^{\prime} \mathrm{N}, 59^{\circ} 48^{\prime} \mathrm{E}$, at a water depth of $2027 \mathrm{~m}$ (Fig. 1). Samples were taken from the upper $40 \mathrm{~m}$ of Hole $722 \mathrm{~B}$; data from the upper $21 \mathrm{~m}$ are presented here. These sediments are contained within lithologic Unit I (Shipboard Scientific Party, 1989), which is composed of alternating light and dark beds of foraminifer-bearing nannofossil ooze, nannofossil ooze/chalk, and marly nannofossil ooze/ chalk. Sampling interval for this study was $20 \mathrm{~cm}$, which is equivalent to a $4.3 \mathrm{k} . \mathrm{y}$. sampling interval at an average sedimentation rate of $4.5 \mathrm{~cm} / \mathrm{k} . \mathrm{y}$. (Clemens and Prell, this volume).

Samples used in this study are splits of the samples used by Clemens and Prell (this volume). Samples for this study were treated with $30 \%$ hydrogen peroxide, buffered with ammonium hydroxide, to remove organic matter, and with glacial acetic acid to remove biogenic carbonate. The remainder of the sample preparation followed the general procedures outlined by Krissek $(1982,1989)$. Residues were freeze-dried, and approximately $100 \mathrm{mg}$ of dried bulk residue were weighed and mixed with $10 \%$ by weight boehmite $(\mathrm{AlOOH})$, which serves as an internal standard. The mixtures were back-loaded as powders into random mounts for XRD analysis.

All slides were solvated with warm ethylene-glycol vapor for $8-12 \mathrm{hr}$ immediately preceding analysis on a Philips diffractometer. Slides were step-scanned at $0.02^{\circ} 2 \theta /$ step and $3 \mathrm{~s} / \mathrm{step}$ with Ni-filtered $\mathrm{CuK}$-alpha radiation. Data were plotted by printer. The 15-18 $\AA$ smectite $(001), 10.4-10.8 \AA$ palygorskite (110), $10 \AA$ illite (001), $6.11 \AA$ boehmite $(020), 4.26 \AA$ quartz (100), $4.02 \AA$ plagioclase (201), $3.57 \AA$ kaolinite (002), $3.54 \AA$ chlorite (004), and $2.89 \AA$ dolomite (104) peak areas were measured with a polar planimeter.

Under conditions of uniform grain size and uniform mineral chemical/structural composition, calibration curves can be constructed to calculate mineral abundances from mineral/boehmite peak area ratios (Gibbs, 1967; Scheidegger and Krissek, 1982; Krissek, 1982). Because bulk samples from Site 722 were analyzed, grain sizes within the pressed powders were not uniform and orientation effects may have been important. These conditions violate criteria needed to accurately apply calibration curves, so the mineral/boehmite peak area ratios measured in this study have not been converted to mineral abundances. As a result, variations in the abundance of a single mineral (e.g., 

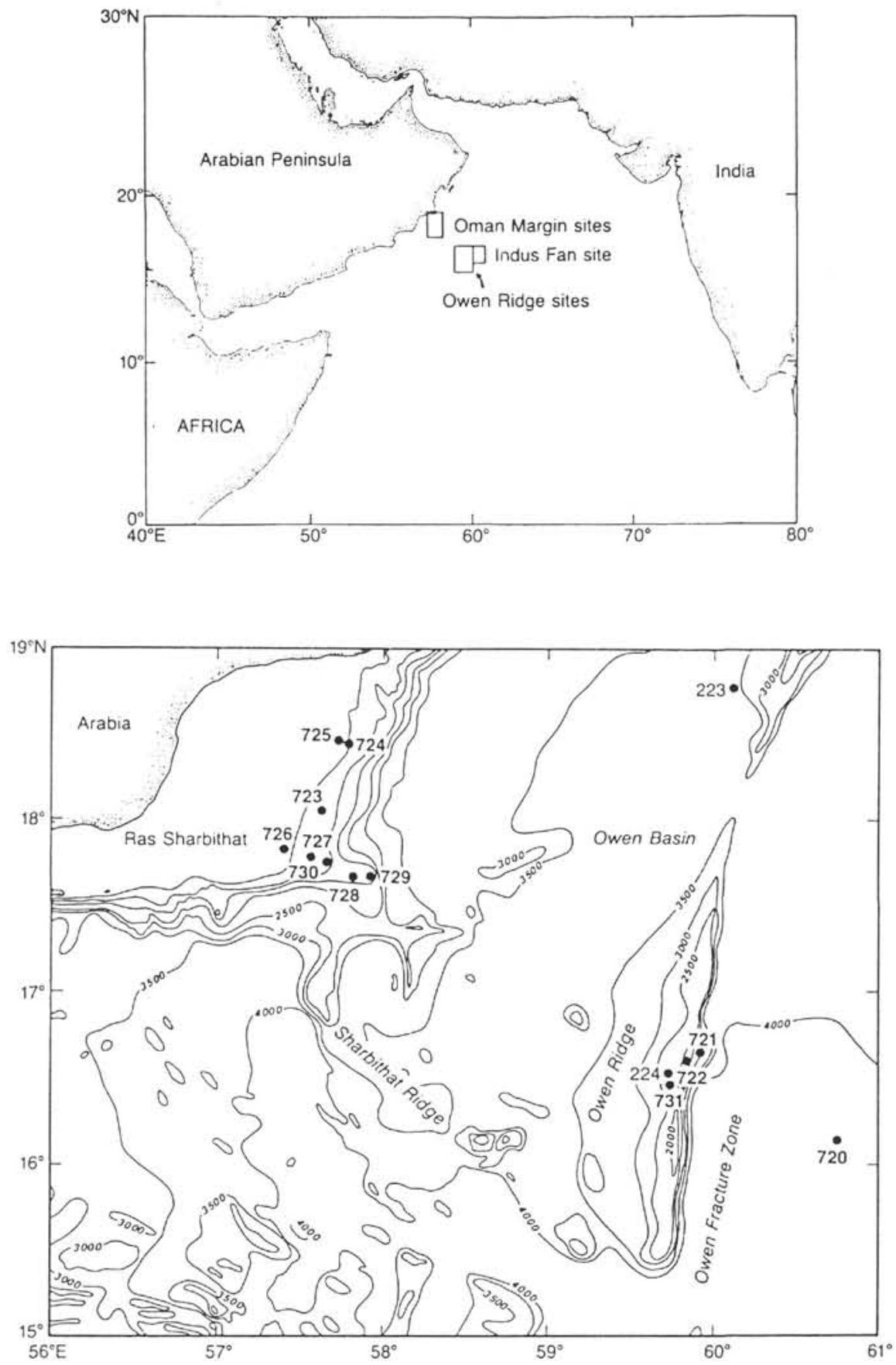

Figure 1. Location map of ODP Leg 117 sites in the Arabian Sea, including Site 722 on the Owen Ridge (from Prell, Niitsuma, et al., 1989).

quartz) can be described using downcore changes in the peak area ratio of that mineral. Absolute abundances of two or more minerals cannot be compared, however.

Analytical precision was evaluated by analyzing replicate slides of six samples, and is estimated as follows (given as absolute mineral/boehmite peak area ratios): \pm 0.07 for smectite, \pm 0.09 for palygorskite, \pm 0.08 for illite, \pm 0.22 for quartz, \pm 0.15 for plagioclase, \pm 0.07 for kaolinite, \pm 0.13 for chlorite, and \pm 0.21 for dolomite. Scheidegger and Krissek (1982) and Krissek (1982) have demonstrated that absolute abundances, determined from mineral/boehmite peak area ratios using calibration curves, are accurate at $\pm 5 \%$ for smectite, $\pm 2 \%$ for chlo- rite and illite, and $\pm 1 \%$ for quartz and plagioclase feldspar. Absolute abundances inferred from the peak area ratios measured in this study would have lower accuracies than those cited by Scheidegger and Krissek (1982) and Krissek (1982), because of the grain size variations described earlier.

The peak area ratio data were examined for variable-to-variable relationships by R-mode factor analysis, using the FACTOR ANALYSIS procedure of the StatView $512+$ software package (Brainpower, Inc., 1986). The final factor analysis results were obtained by an ORTHOTRAN (oblique) refinement of a VARIMAX solution; all factor intercorrelations following the ORTHOTRAN refinement were less than 0.45 . The terminology 
employed here is that of StatView 512 + (Brainpower, Inc., 1986) and Davis (1986), which labels the coefficients that indicate the importance of each variable on a factor as "loadings," and the coefficients of factor importance to each sample as "scores."

Ages for these samples were obtained from the age model constructed for $0-780 \mathrm{ka}$ at Site 722 by Clemens and Prell (this volume), based on correlation of the oxygen isotope record from Hole 722B to the SPECMAP stacked oxygen isotope record (Imbrie et al., 1984). Temporal and frequency relationships between the importance of each mineral assemblage (factor) and indicators of monsoon strength, source area aridity, and global paleoclimate (Clemens and Prell, this volume) were evaluated using cross spectral analysis. Records were interpolated at $2 \mathrm{k}$.y. intervals for the cross-spectral analysis, and all analyses were conducted using standard techniques (Imbrie et al., 1989; Jenkins and Watts, 1968).

\section{DATA}

Mineral/boehmite peak area ratios are plotted as a function of age in Figure 2, and are tabulated in the Appendix. Each record exhibits significant variability (greater than the analytical uncertainty) over the interval studied, but none of the records
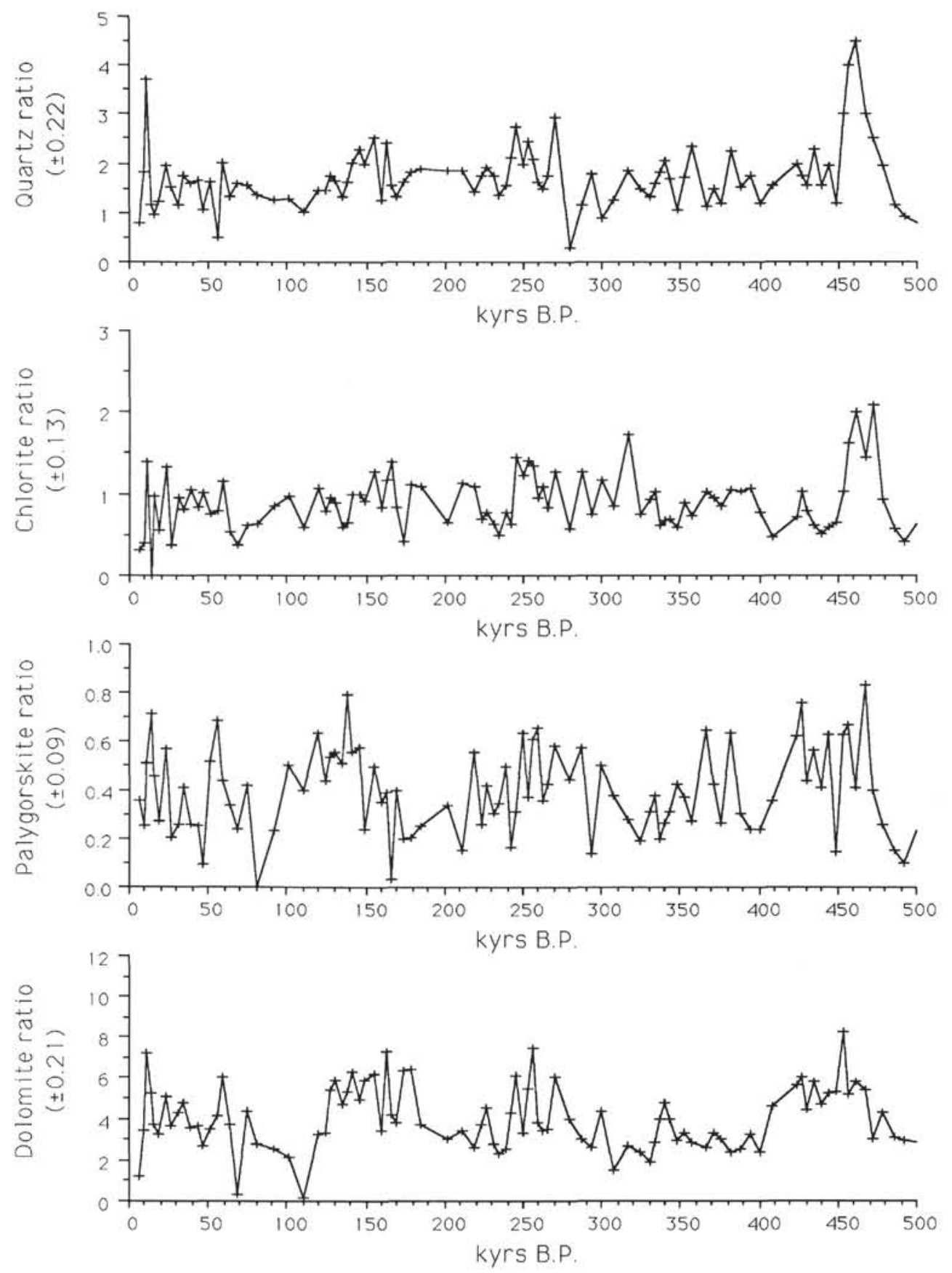

Figure 2. Mineral abundance data (mineral/boehmite peak area ratios) at ODP Site 722, plotted as a function of age. All records are dominated by short-term (10-100 k.y.) variability. 

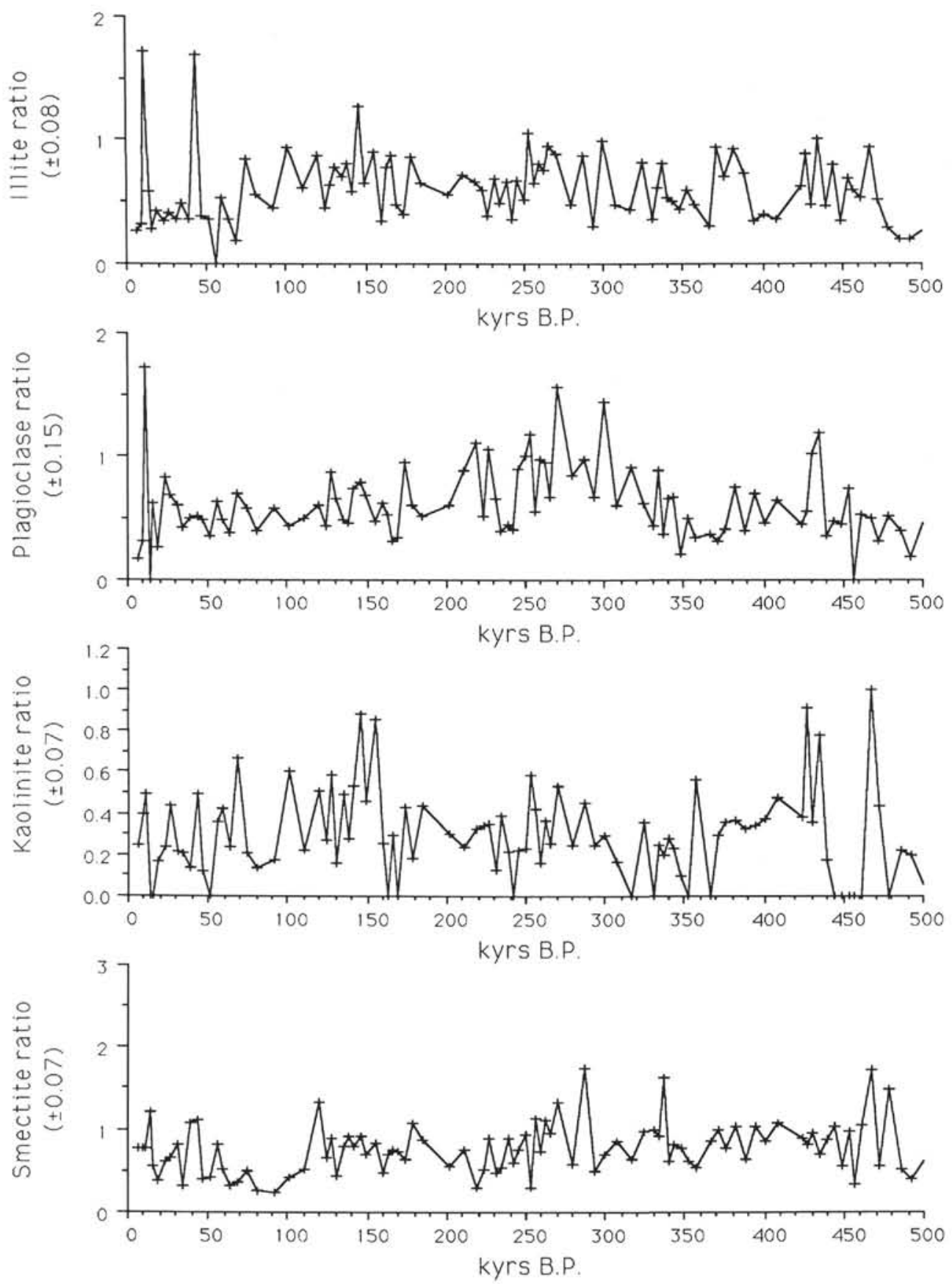

Figure 2 (continued).

exhibits a consistent long-term increase or decrease over this time. It is interesting to note, however, that several records do exhibit shorter-term variations of consistent length; these are most obvious as cycles of approximately $100 \mathrm{k} . \mathrm{y}$. duration in the palygorskite/boehmite and dolomite/boehmite ratios.

\section{DISCUSSION}

\section{Paleoclimatic Significance of Mineral Assemblages in} Owen Ridge Eolian Sediments, Time Series Analysis

The important terrigenous minerals at Site 722 are smectite, illite, palygorskite, kaolinite, chlorite, quartz, plagioclase feldspar, and dolomite, all of which have been identified as impor- tant constituents in studies of Holocene and modern Arabian Sea sediments and aerosols (Sirocko and Sarnthein, 1989; Debrabant et al., this volume; Chester et al., 1985; Kolla et al., 1976, 1981). Previous studies have used geographic patterns of mineral abundances or fluxes to infer modern source areas for each, as summarized in the "Introduction." Because these studies generally examined surface or near-surface sediments, however, temporal changes in the mineral assemblages derived from these sources could not be considered. The Site 722 samples span the past $500 \mathrm{k} . y$., providing an excellent opportunity to evaluate temporal changes in mineral associations and to identify the longer-term variability in sediment supply to the Arabian Sea. 
Mineral associations have been identified by performing an R-mode factor analysis, with an ORTHOTRAN refinement of a VARIMAX solution (Brainpower, Inc., 1986). This application assumes that all relevant matrix variance has been included when the sum of the proportionate contributions of the eigenvalues exceeds 0.75 ; for the Site 722 data, four factors are required to exceed that value. The contributions of the four factors to explaining the original variance, and their proportionate variance contributions following the ORTHOTRAN/VARIMAX solution are listed in Table 1. Loadings for each variable on each of the four factors are listed in Table 2.

Temporal variations in the importance of these four factors can be interpreted to emphasize either of two effects: (1) variations in the importance of input from specific source areas caused by changes in transport paths (e.g., monsoon position), assuming that the mineralogy of materials derived from those sources remained constant through glacial/interglacial climatic fluctuations; or (2) climatically controlled changes in the mineralogy of sediments derived from less precisely located source areas during glacial/interglacial fluctuations, assuming that summer monsoon winds dominated eolian input over that time. The latter approach is chosen here for three reasons: (1) continental climates are known to have changed significantly during glacial/ interglacial fluctuations (Street and Grove, 1979; van Campo et al., 1982; Prell and van Campo, 1986), suggesting that weathering conditions and the mineral assemblages produced should also have changed; (2) the importance of monsoonal circulation throughout the past $1 \mathrm{~m}$.y. has been recognized in marine faunal indicators of monsoon-induced upwelling (Prell and Curry, 1981; Prell, 1984) and eolian grain-size and MAR records on the Owen Ridge (Clemens and Prell, this volume, 1990); and (3) potential source areas for the important minerals and mineral assemblages are relatively extensive, so that the variations in wind trajectories and dust transport paths expected during glacial/interglacial cycles would not have changed source areas enough to explain the observed variations in mineralogy.

Table 1. Proportions of data variance explained by first four factors after initial R-mode analysis and following the ORTHOTRAN/VARIMAX solution refinement.

\begin{tabular}{lcccc}
\hline \multicolumn{1}{c}{ Proportion (\%) } & Factor 1 & Factor 2 & Factor 3 & Factor 4 \\
\hline Of original variance & 38 & 14 & 12 & 10 \\
Of variance after & 38 & 25 & 17 & 20 \\
$\quad$ orthotran/varimax & & & & \\
\hline
\end{tabular}

Table 2. Loadings of each variable on each of the four factors extracted by R-mode factor analysis from the mineral/boehmite peak area ratio data. Factor 1 is dominated by quartz, chlorite, and dolomite, Factor 2 is dominated by illite, plagioclase, and kaolinite, Factor 3 is dominated by smectite, and Factor 4 is dominated by palygorskite and dolomite.

\begin{tabular}{lrrrr}
\hline \multicolumn{4}{c}{ Factor Loadings } \\
Variable & Factor 1 & Factor 2 & Factor 3 & Factor 4 \\
\hline Smectite & 0.09 & 0.02 & 0.83 & 0.00 \\
Palygorskite & -0.17 & 0.04 & 0.04 & 0.82 \\
Illite & 0.15 & 0.55 & 0.12 & 0.07 \\
Quartz & 0.75 & -0.05 & 0.11 & 0.00 \\
Plagioclase & 0.14 & 0.68 & -0.39 & -0.02 \\
Kaolinite & -0.24 & 0.75 & 0.24 & -0.02 \\
Chlorite & 0.77 & 0.00 & -0.02 & -0.09 \\
Dolomite & 0.38 & -0.08 & -0.09 & 0.54 \\
\hline
\end{tabular}

In this context, the factors can be summarized and interpreted as follows:

1. Factor 1 is dominated by high positive loadings for quartz and chlorite, and an intermediate positive loading for dolomite. The largest negative loadings are for kaolinite and palygorskite, but these values are significantly lower than the maximum positive values. As a result, Factor 1 is an indicator of the association of quartz and chlorite, and to a lesser extent, dolomite. Of the two most important minerals, chlorite is more sensitive to the weathering environment. Chlorite is only stable under conditions of very minimal chemical weathering (Dixon and Weed, 1977; Velde, 1985), whereas quartz is readily produced from a variety of source lithologies under a range of weathering conditions. Dolomite is also more stable than chlorite (Dixon and Weed, 1977), being recycled from older sedimentary rocks and produced by desiccation of sabkhas. The importance of chlorite in Factor 1 suggests that this mineral assemblage formed in, or was recycled from, relatively arid source regions. Detrital chlorite is most readily generated either as an inherited mineral from igneous or metamorphic source lithologies, or as a weakly altered product of ferromagnesian minerals (Dixon and Weed, 1977). Appropriate source lithologies have been common in IranMakran, Oman and the Arabian Peninsula, and East Africa throughout the past $500 \mathrm{k} . \mathrm{y}$. The importance of dolomite in Factor 1 suggests that at least some of this assemblage was derived from Oman and the Arabian Peninsula, since dolomitic source lithologies are best exposed there (Sirocko and Sarnthein, 1989). All of these potential source areas are suitably located to supply material to Site 722 via southwesterly or northwesterly summer winds.

2. Factor 2 is dominated by high positive loadings for kaolinite, plagioclase, and illite; loadings for all other minerals are very low. Of the three important minerals, illite and plagioclase are the most environmentally sensitive, whereas kaolinite may be recycled from older, more intensely weathered rocks. Illite is formed by degradation of mica or by weathering potassium feldspars under conditions of limited precipitation (Dixon and Weed, 1977; Blatt et al., 1980); these conditions are also favorable for preservation of plagioclase feldspar. Kolla et al. (1981) and Sirocko and Sarnthein (1989) have identified several sources that presently supply illite to the Arabian Sea: Iran-Makran, the Arabian Peninsula, and Somalia. As a result, appropriate source rocks have been available in several areas to generate the Factor 2 mineral assemblage during appropriate weathering conditions over the last 500 k.y.

3. Factor 3 is dominated solely by smectite, although plagioclase has a moderate negative loading. Smectite is produced by moderate chemical weathering of a wide variety of source lithologies (Velde, 1985). Under such conditions, plagioclase feldspar is relatively unstable. The major source of smectite to the modern eastern Arabian Sea is the Deccan Trap basalts, but appropriate source lithologies have also been exposed in the Arabian Peninsula and East Africa during the past 500 k.y. (Kolla et al., 1981).

4. Factor 4 is dominated by palygorskite and, to a lesser extent, dolomite. Palygorskite is formed in marine settings, alkaline lakes, and calcrete/caliche profiles (Velde, 1985), and is present in a variety of carbonate and evaporite deposits. Palygorskite is highly susceptible to decomposition during chemical weathering (Dixon and Weed, 1977; Velde, 1985). Thus, its importance in Factor 4 indicates an assemblage derived from an arid source region. The major sources to the modern Arabian Sea are the arid regions of the Arabian Peninsula and East Africa (Kolla et al., 1981; Sirocko and Sarnthein, 1989), but the importance of dolomite in Factor 4 suggests input from the Ara- 
bian Peninsula, where carbonate source lithologies are common (Sirocko and Sarnthein, 1989).

In summary, the mineral assemblages of Factors 1, 2, and 4 record sediment production under arid conditions and limited chemical weathering, whereas the assemblage of Factor 3 records enhanced chemical weathering effects. The importance of dolomite in assemblages grouped as Factors 1 and 4 suggests a sustained production of both assemblages in Oman and the
Arabian Peninsula, whereas the areas supplying the Factor 2 and 3 assemblages are less well-defined.

Temporal variations in the relative importance of the four mineral assemblages (factors) can be estimated by examining the time-series of factor scores for each (Fig. 3; Appendix). None of the time-series exhibits either significant long-term trends or major step-like variations; instead, each time-series is dominated by shorter term (scales of 10-100 k.y.) variability. This shorter-term variability is most readily observed in the loadings on Factor 4,
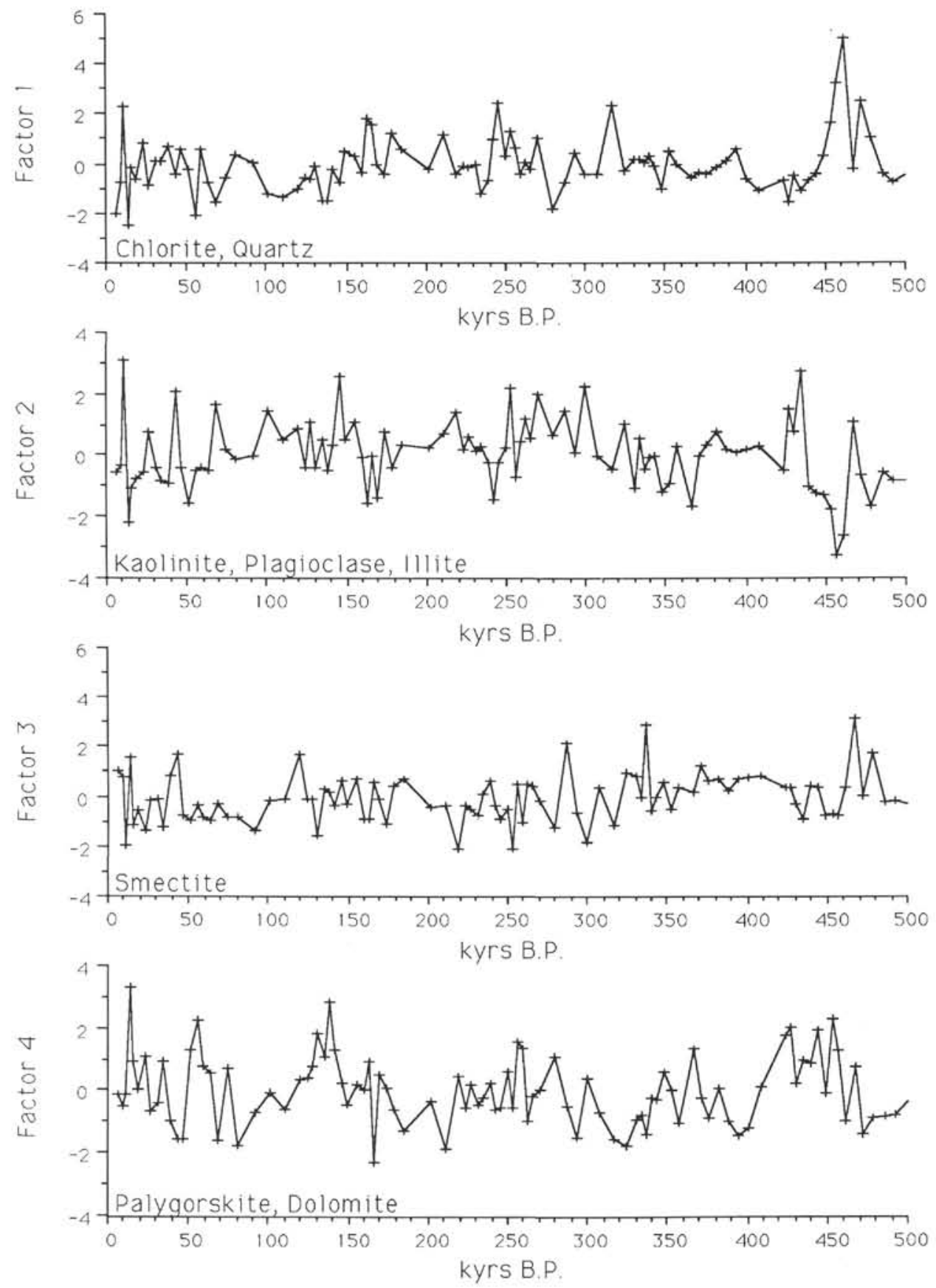

Figure 3. Scores for the four factors at Site 722 defined by R-mode factor analysis and an ORTHOTRAN/VARIMAX solution refinement. Loadings of each variable on each factor are listed in Table 2 . Factors 1,2 , and 4 are interpreted as indicators of arid conditions, while Factor 3 is an indicator of more humid weathering. Site $722 \mathrm{~B}$ eolian MAR and SPECMAP oxygen isotope records provided for comparison. 

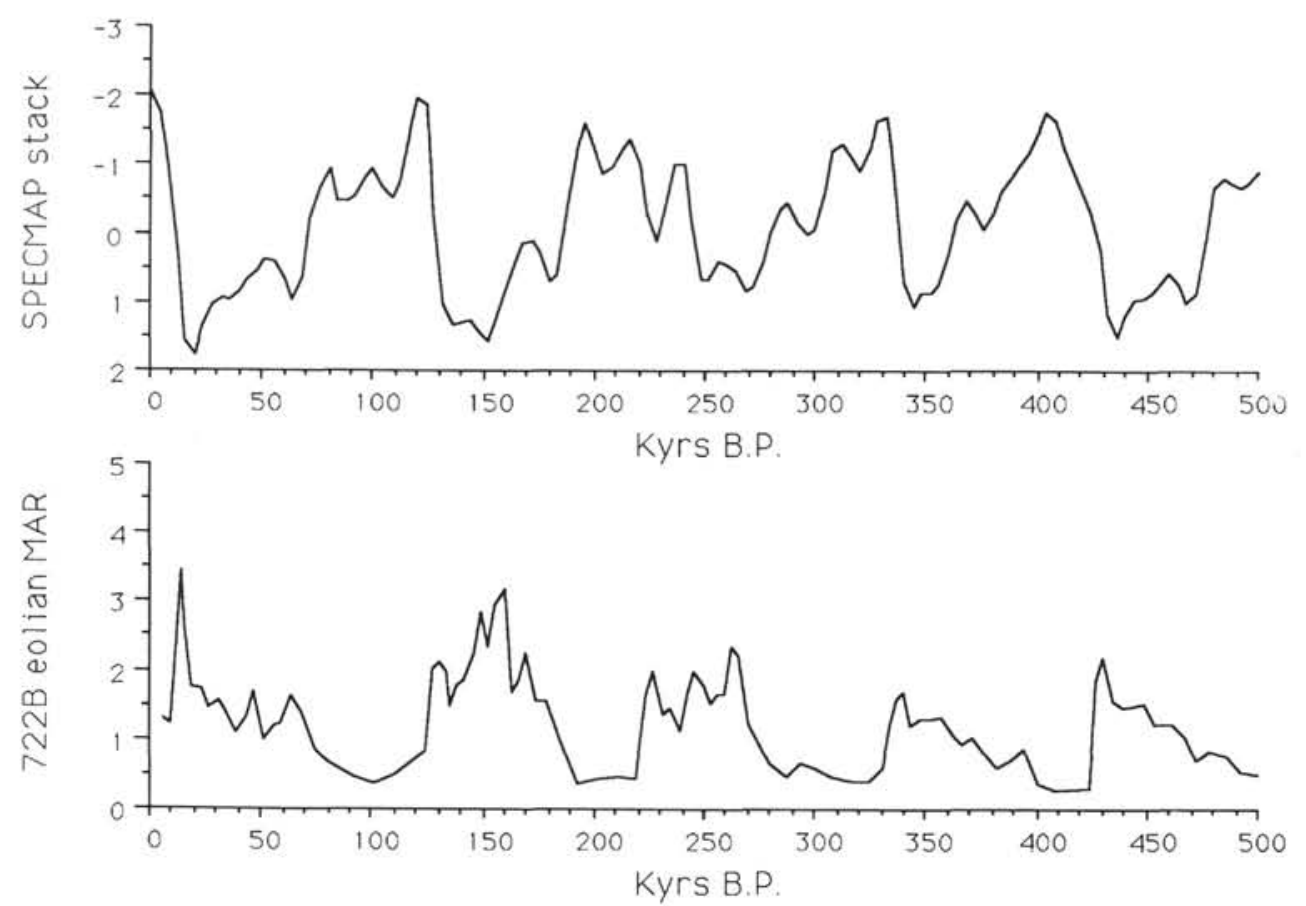

Figure 3 (continued).

where quasi-cyclic variations over approximately 100 k.y. intervals are overlain by fluctuations on even shorter time scales.

Detailed interpretations of source area paleoclimates directly from the factor scores are complicated by the predominance of short-term variability in all four time-series; the variability arises at least in part because weathering assemblages and erosional products may not respond immediately and directly to climatic changes. Instead, the mineral assemblage deposited at a particular time may combine the weathering products of both older and contemporaneous climates. The complications imposed by such "lag" effects and by the nonlinear response of weathering products to climate change can be illustrated by examining the factor scores for the last glacial maximum (isotopic stage 2, centered at approximately $18 \mathrm{ka}$; Imbrie et al., 1984) and the last interglacial (isotopic stage 5.5, centered at approximately $125 \mathrm{ka}$; Imbrie et al., 1984). These data are summarized in Table 3. Pollen assemblages (van Campo et al., 1982; Prell and van Campo, 1986 ) indicate that the last glacial maximum was relatively arid, but the $18 \mathrm{ka}$ sample does not have strong scores for the three "arid" factors. In contrast, pollen data indicate increased humidity at the last interglacial, while that sample has strong scores for the "arid" factors 2 and 4.

The potential complications posed by the lack of equilibrium between extant climate and the mineral assemblages deposited are further illustrated in Table 4 , where scores for each factor

Table 3. Factor scores for samples from the last glacial maximum (18 ka) and the last interglacial $(125$ ka). Scores do not clearly indicate dominance by arid and humid weathering conditions, respectively.

\begin{tabular}{ccccc}
\hline \multirow{2}{*}{$\begin{array}{c}\text { Sample age } \\
(\mathrm{ka})\end{array}$} & Factor 1 & Factor 2 & Factor 3 & Factor 4 \\
\hline 18 & -0.60 & -0.76 & -0.53 & 0.04 \\
125 & -0.60 & 1.07 & -0.10 & 0.78 \\
\hline
\end{tabular}

Table 4. Factor scores averaged over glacial and interglacial stages, as defined by marine oxygen isotope records (Imbrie et al., 1984). Even-numbered stages are glacials, odd-numbered stages are interglacials. Averaged factor scores do not indicate that glacial stages were dominated by products of arid weathering environments, nor were interglacials dominated by products of humid weathering.

\begin{tabular}{rrrrr}
\hline \multicolumn{5}{c}{ Average Factor Scores } \\
Stage & Factor 1 & Factor 2 & Factor 3 & Factor 4 \\
\hline 1 & -0.16 & 0.74 & -0.03 & -0.25 \\
2 & -0.60 & -1.15 & -0.36 & 1.33 \\
3 & -0.26 & -0.22 & -0.13 & -0.09 \\
4 & -0.57 & 0.25 & -0.66 & -0.10 \\
5 & -0.61 & 0.44 & -0.21 & -0.11 \\
6 & 0.09 & 0.13 & -0.10 & 0.32 \\
7 & -0.08 & 0.21 & -0.46 & -0.36 \\
8 & 0.21 & 0.84 & -0.39 & -0.13 \\
9 & 0.40 & -0.08 & 0.64 & -1.19 \\
10 & -0.07 & -0.38 & -0.05 & -0.19 \\
11 & -0.32 & 0.03 & 0.66 & -0.39 \\
12 & 0.63 & 0.02 & 0.14 & 1.05 \\
13 & 0.25 & -0.80 & 0.88 & -0.45 \\
\hline
\end{tabular}

have been averaged over the duration of each isotopic stage from 1 through 13 (after Imbrie et al., 1984). If all mineral assemblages quickly equilibrated with contemporaneous climate, then the relatively humid interglacial stages $(1,5,7,9,11$, and 13) should have low scores for Factors 1,2 , and 4, and high positive scores for Factor 3. This condition is somewhat met during stages 9,11 , and 13 , but not during the more recent interglacials. Under conditions of rapid equilibration during glacial stages (increased aridity), high positive scores should occur for Factors 1, 2 , and 4 , and a high negative score should occur for Factor 3. Several glacial stages $(2,4,8,12)$ show appropriate scores for one or two factors, but none fulfill these conditions for all fac- 
tors. In addition, stage 1 (an interglacial) has a high positive score for Factor 2, suggesting input under "arid" conditions. In general, then, these results indicate that terrigenous mineral assemblages deposited in the western Arabian Sea during the past $500 \mathrm{k}$.y. were influenced by a range of controls, so that their record of source area paleoclimate is not obvious or direct.

\section{Paleoclimatic Significance Of Mineral Assemblages In Owen Ridge Eolian Sediments, Frequency Domain Analysis}

As discussed previously, the comparison of factor scores to the isotopically derived record of paleoclimate in the time domain does not directly support our mineralogy-based interpretation that Factors 1, 2, and 4 are related to source area aridity and, therefore, to glacial/interglacial cycles. An alternative approach is to compare the records in the frequency domain, using cross-spectral analysis. This approach is particularly useful when analyzing complicated records, because each record is broken into its component frequencies of variation; in the case of the factor scores, this method of analysis is useful for separating the paleoclimatically forced signature of weathering from variations produced by other mechanisms. The constituent frequencies of variation can then be compared between records to identify their coherency (linear relationships), and can also clarify lead/lag relationships that result from a variety of processes, including the kinetics of weathering under changing climatic regimes. If our hypothesis about the significance of Factors 1, 2, and 4 is correct, then the scores for those factors should be coherent with (i.e., linearly related to) the terrigenous MAR record, which has been shown to have a strong positive correlation to glacial/ interglacial cycles (Clemens and Prell, this volume, 1990).

The time-series of scores for each factor was subjected to spectral analysis, and the results are illustrated in Figure 4. The spectra of factor scores were compared with the spectra of eolian MAR and eolian grain size at Site 722 (Clemens and Prell, this volume), and global ice-volume (the SPECMAP stacked oxygen isotope record of Imbrie et al., 1984) over the interval 6-500 ka. Clemens and Prell (this volume, 1990) have demonstrated that eolian MAR records from the Owen Ridge contain spectral peaks at periods of $100,40-42,22-24$, and 18-20 k.y. (the primary Milankovitch frequencies), and that these records are coherent with the marine oxygen isotope record and glacial loess sections from central China. Because of these relationships, they interpret the eolian MAR as an indicator of past dust source-area aridity, driven by glacial/interglacial climatic fluctuations. The eolian grain size record varies independently of the MAR, but is well correlated with biotic indices of winddriven upwelling. For this reason, the grain size record is interpreted as an index of summer monsoon wind strength.

Cross-spectral analyses identified significant coherence and zero phase relationships between the Site 722 factor scores and the Site 722 eolian MAR, and between the Site 722 factor scores and the marine oxygen isotope record. Because the Site 722 eolian MAR record is the more direct indicator of paleoclimatic aridity and because the linear relationship between the eolian MAR and marine oxygen isotope records is presented elsewhere (Clemens and Prell, this volume, 1990), we present only the cross-spectra that compare the scores for the mineralogic factors to the eolian MAR record from Site 722 (Fig. 4). Poor coherence is demonstrated by the cross-spectral analysis of the Site 722 factor scores and the Site 722 eolian grain size records, supporting the hypothesis that variations in Factors 1,2 , and 4 are responses to changes in source area aridity, instead of wind strength.

The variance spectrum for Factor 1 contains peaks at periods of approximately 117, 71, 33, 23, 21, and 17 k.y. (Fig. 4A); the 23 k.y. (precession) peak shows significant coherence and zero phase relationship with the 23 k.y. eolian MAR spectrum (Figs. $4 \mathrm{~A}$ and 5). The variance spectrum for Factor 2 contains peaks at approximately $111,37,27,21$, and 18 k.y.; the Factor 2 record shows relatively weak coherence with the eolian MAR at the 41 k.y. (obliquity) band (Figs. 4B and 5). This association with the known period of obliquity, and the zero phase relationship, support the significance of this coherence. The variance spectrum for Factor 3 contains peaks at approximately 69, 43, 35, and 28-20 k.y., but shows no significant coherence with the eolian MAR record (Fig. 4C). The variance spectrum for Factor 4 contains peaks at approximately $110,38,28$, and 20 k.y., and shows significant coherence and a zero phase relationship with eolian MAR at the 100 k.y. (eccentricity) band (Figs. 4D and 5).

Previous high-resolution studies of paleoclimatic indicators in the Arabian Sea (Prell and Curry, 1981; Prell, 1984; Prell and van Campo, 1986; Clemens and Prell, this volume, 1990) have emphasized the importance of variations at the primary Milankovitch frequencies (eccentricity, 100 k.y.; obliquity, 41 k.y., precession, 23 k.y.). These influences are also evident in the Site 722 factor spectra, where frequencies at or close to the primary Milankovitch frequencies are identified for each factor (eccentricity and precession in Factor 1, eccentricity, obliquity and precession in Factor 2, obliquity and precession in Factor 3, and eccentricity, obliquity, and precession in Factor 4).

The spectra for Factors 1, 2, and 4 exhibit significant coherency and zero phase relationships with the Site 722 eolian MAR over the primary Milankovitch frequencies (Figs. 4 and 5), indicating direct linear relationships between a portion of the increased production of each arid mineral assemblage (factor) and the increased total eolian flux to the Owen Ridge. We have previously demonstrated a possible disequilibrium between extant climate (indicated by global ice volume) and the production/deposition of arid mineral assemblages (see Tables 3 and 4). The spectral comparisons provide two lines of evidence to explain that disequilibrium: (1) the spectrum for each factor contains peaks at the primary Milankovitch frequencies, but also contains peaks not observed in the global ice volume record (Fig. 4). The mechanisms that force the variations at non-Milankovitch frequencies are not known at this time, but the presence of such variations re-emphasizes the complex nature of the weathering/ erosion/deposition cycle. As a result of these variations at nonMilankovitch frequencies, each factor score record and the global ice volume record cannot vary synchronously in the time domain; and (2) the spectral comparisons indicate a lag between maximum ice volume and the maximum importance of arid mineral assemblages over the eccentricity and precession bands (Fig. 5). More specifically, maximum source area aridity, as indicated by maximum eolian MAR and maximum importance of the individual mineral assemblages, follows maximum global ice volume by $8 \mathrm{k}$.y. over the eccentricity band, by about $3 \mathrm{k} . \mathrm{y}$. over the precession band, and is in phase over the obliquity band. These lags also reduce the correlation between the factor scores and global climate (as expressed by the oxygen isotope stages). While a general aridity control on the variability of Factors 1,2 , and 4 is understandable, the detailed associations identified by the cross-spectral analysis are more difficult to explain. On the basis of available data from the Arabian Sea, it is not immediately obvious why the chlorite/quartz assemblage (Factor 1) responds predominantly to $23 \mathrm{k} . \mathrm{y}$. aridity cycles, while the illite/plagioclase/kaolinite assemblage (Factor 2) responds to $41 \mathrm{k} . y$. aridity cycles, and the palygorskite/dolomite assemblage responds to $100 \mathrm{k}$.y. cycles. The association of each mineral assemblage with a specific primary Milankovitch frequency may reflect the combined effects of two processes: (1) the rates of mineral weathering/formation, so that more resistant primary minerals are enriched during longer climatic cycles; and (2) the role of climatic variations at each frequency in develop- 
A $_{1.00}$

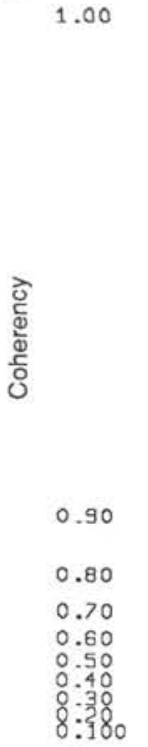

Bandwidth for 110 lags

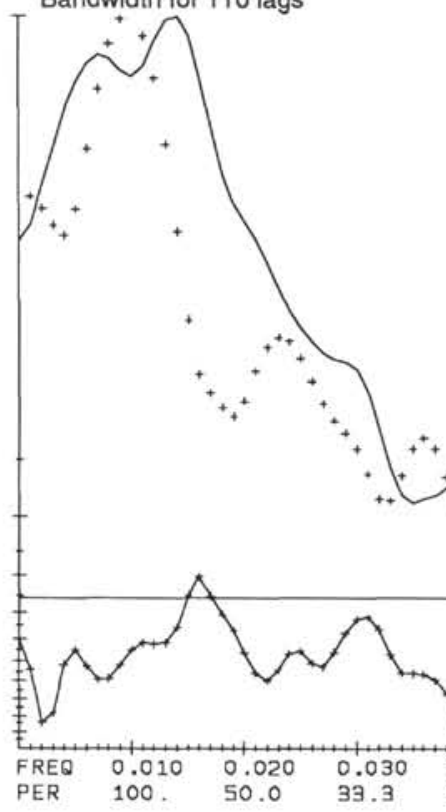

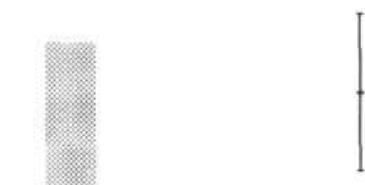

C.I. at the $80 \%$ leve

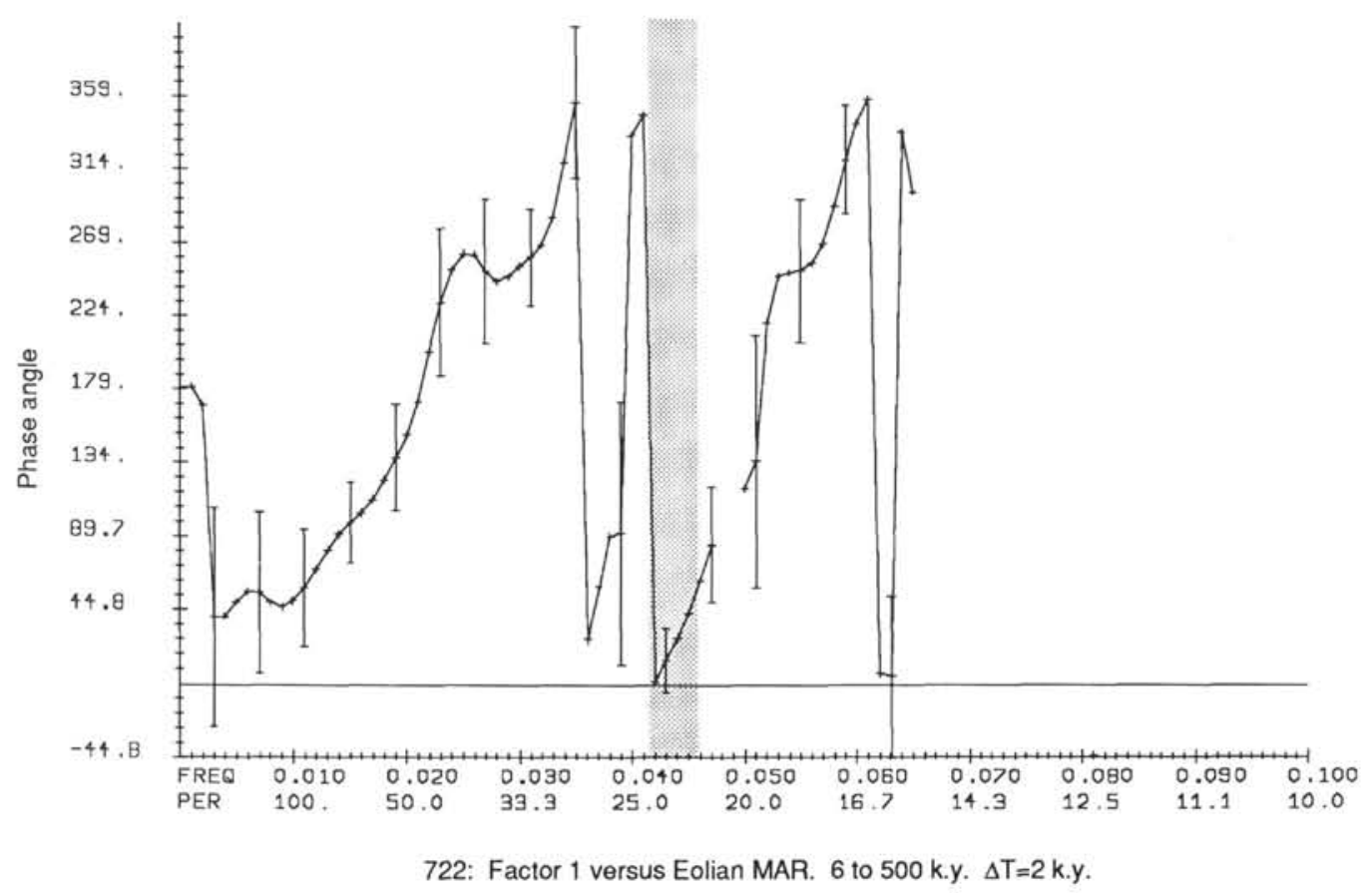

Figure 4. Normalized variance spectra of Site 722 factor scores (solid line) and Site 722 eolian MAR (crosses) and the coherency spectrum between the factor scores and the eolian MAR (crosses with solid line) for the interval from 6 to 500 k.y. Variancy spectra are plotted on arbitrary log scales and coherency spectrum is plotted on a hyperbolic arctangent. Frequencies are in cycles/k.y. Sampling interval is 2 k.y. Critical value for non-zero coherence at the $80 \%$ confidence interval is shown (solid horizontal line). A. Site 722 Factor 1 scores and eolian MAR. B. Site 722 Factor 2 scores and eolian MAR. C. Site 722 Factor 3 scores and eolian MAR. D. Site 722 Factor 4 scores and eolian MAR.

ing source area conditions favorable for formation/erosion of that mineral assemblage (e.g., the effects of sea level fluctuations or vegetation changes).

For example, chlorite is generally viewed as more susceptible to chemical weathering than illite (Dixon and Weed, 1977; Velde, 1985), so the association of chlorite with the shortest climatic cycles may reflect preferential production/preservation of chlorite during shorter intervals of chemical weathering. Rates of chemical weathering are difficult to measure directly, and such data from the Arabian Sea region are not known. Some useful data from cold arid regions in Antarctica were summarized by Ugolini (1986), where both mica (illite) and chlorite were de- 
B
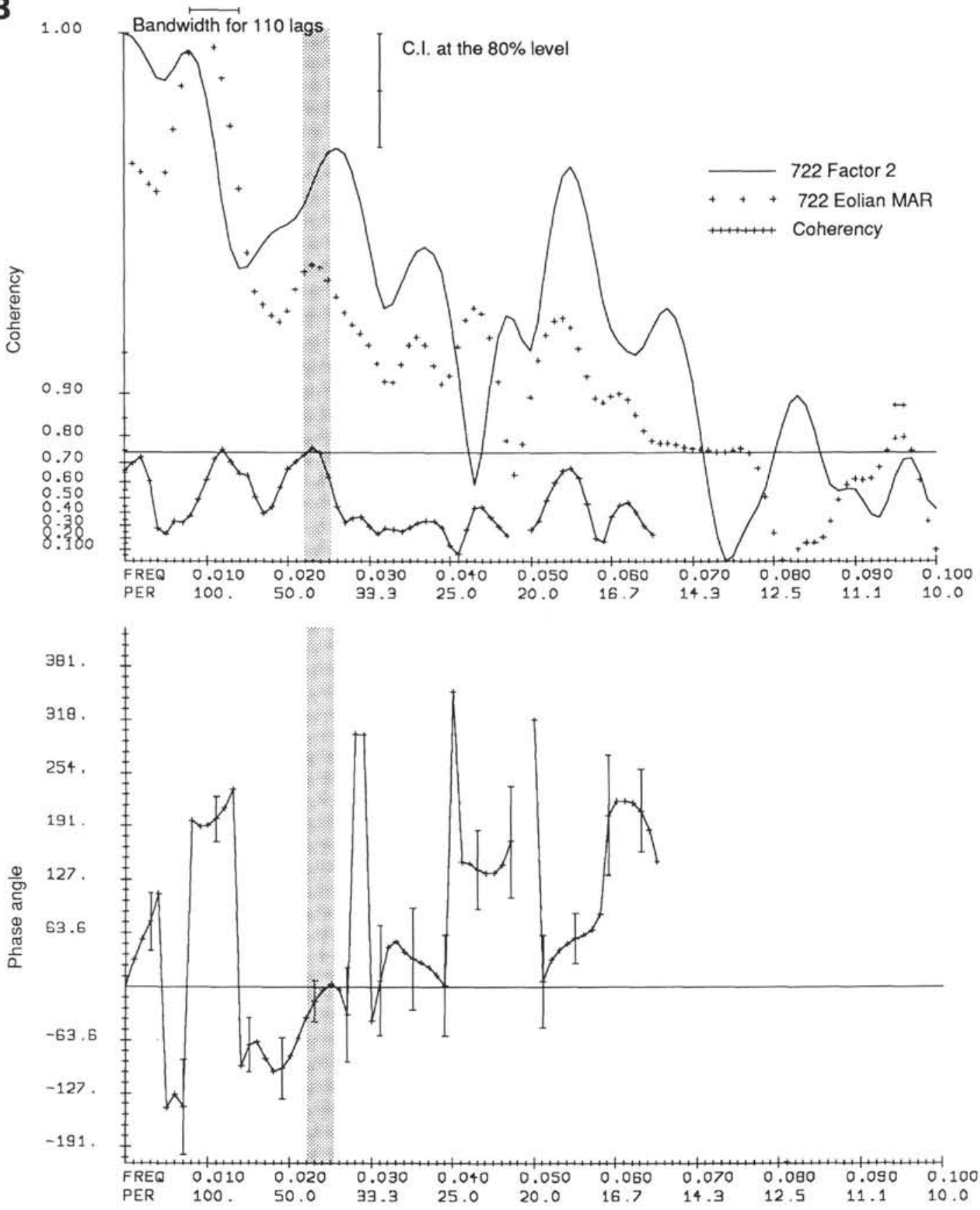

722: Factor 2 versus Eolian MAR. 6 to 500 k.y. $\Delta T=2$ k.y.

Figure 4 (continued).

graded over 17-21 k.y. of exposure. These time scales of weathering are in general agreement with the 23 and $41 \mathrm{k}$.y. periods of climatic change produced by insolation variations. In contrast, palygorskite forms relatively quickly under appropriate chemical conditions (Dixon and Weed, 1977; Velde, 1985; and references therein), so its association with 100 k.y. aridity cycles does not appear to reflect time scales needed for palygorskite formation. Instead, this association may indicate the role of $100 \mathrm{k} . \mathrm{y}$. climatic cycles in developing and desiccating continental environments, such as coastal sabkhas and alkaline lakes, that are suitable for palygorskite formation.

Distinguishing between the effects of mineral susceptibility to weathering and the larger-scale effects of source area change will require a geographically widespread suite of well-dated, highresolution mineralogic records, combined with more detailed knowledge of local paleoclimatic fluctuations in the continental source regions over the past $500 \mathrm{k} . \mathrm{y}$.

\section{SUMMARY}

Terrigenous eolian sediments deposited on the Owen Ridge during the past $500 \mathrm{k} . \mathrm{y}$. are composed of smectite, illite, palygorskite, kaolinite, chlorite, quartz, plagioclase feldspar, and dolomite. This mineralogy is consistent with the compositions of source areas presently supplying sediment to the Arabian Sea. Significant climatic changes have occurred in these source regions over the past $500 \mathrm{k} . \mathrm{y}$, , however, so that the composi- 

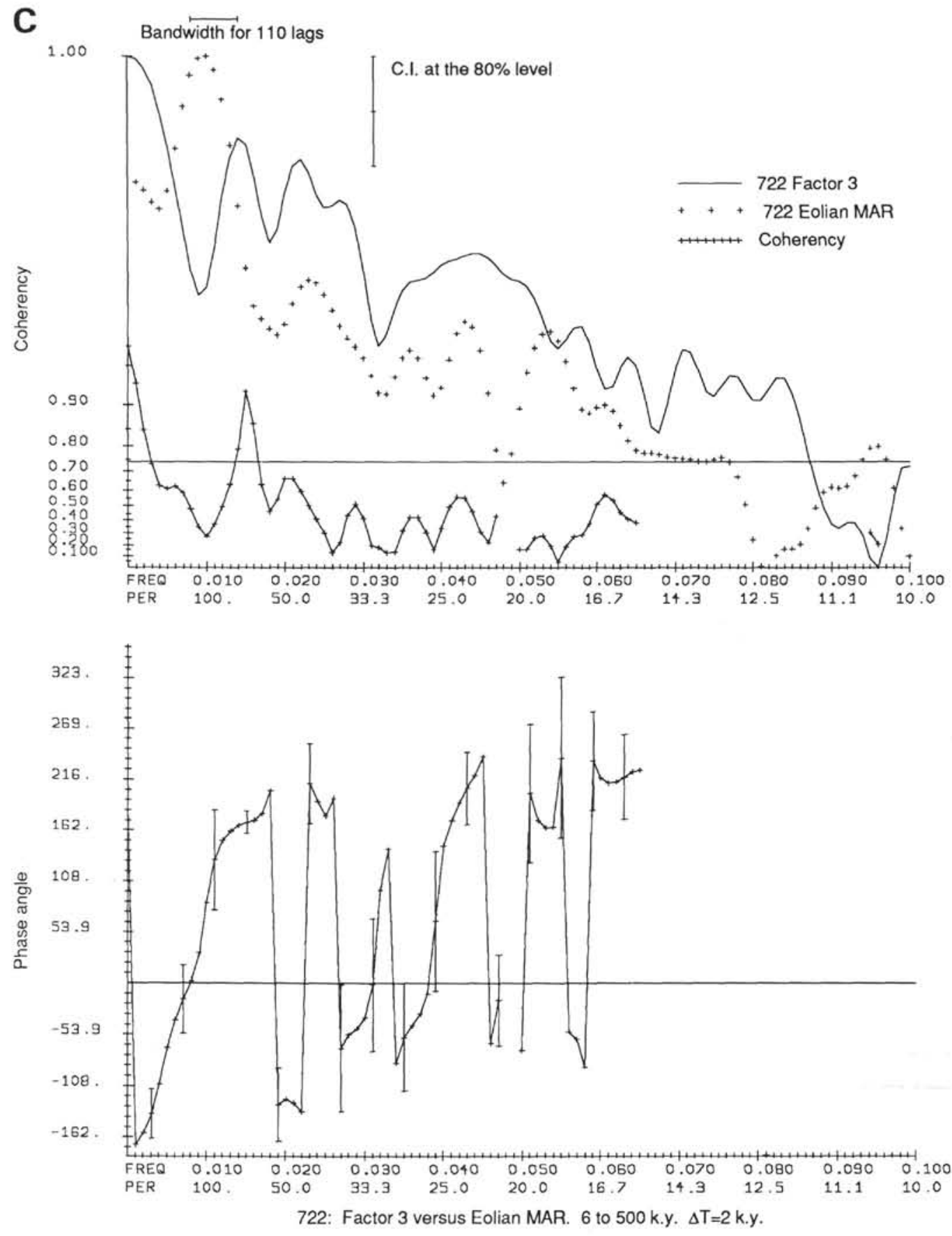

Figure 4 (continued).

tions of sediments supplied from each source may have changed through time. An R-mode factor analysis of the mineral abundances has identified four mineral assemblages present throughout the record at Site 722: a quartz/chlorite/dolomite assemblage (Factor 1), a kaolinite/plagioclase/illite assemblage (Factor 2), smectite (Factor 3), and a palygorskite/dolomite assemblage (Factor 4). Chlorite, illite, and palygorskite are all susceptible to chemical weathering, suggesting that Factors 1, 2, and 4 each reflect arid continental source areas. This interpretation is supported by spectral analysis, which indicates that production of these mineral assemblages increased during more arid glacial intervals. In contrast, Factor 3 is interpreted to record relatively humid source conditions.

Pollen and lake-level data indicate that continental areas around the Arabian Sea became more arid during glacial intervals and more humid during interglacials. Time-series of scores for the "arid" and "humid" factors (1, 2, and 4 vs. 3) are dominated by short-term (10-100 k.y.) variability, and do not correlate well to glacial/interglacial fluctuations in the time domain. These characteristics suggest that local environmental fluctuations were more complex than simple transitions between arid glacials and humid interglacials, that orbital fluctuations were 

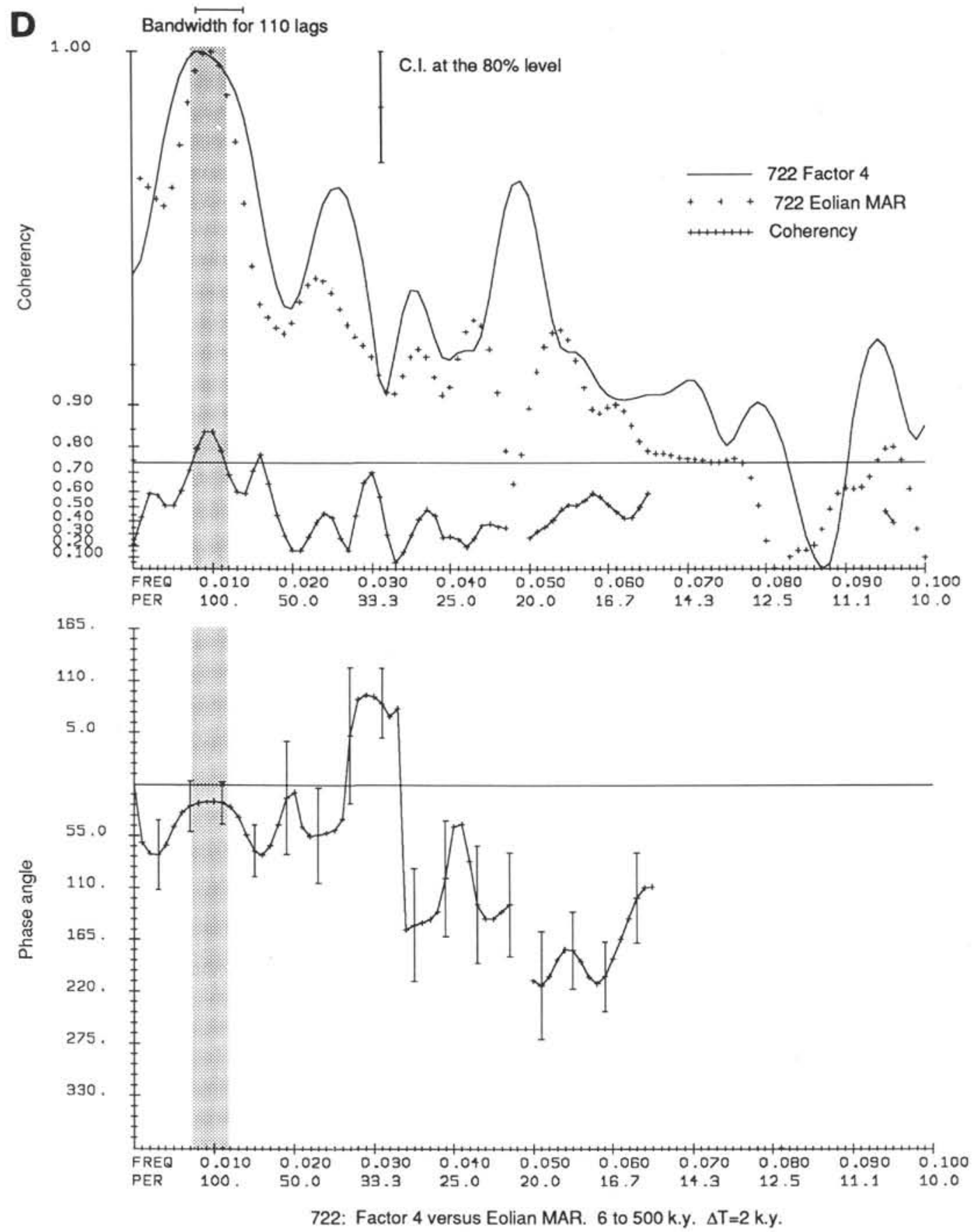

Figure 4 (continued).

not the sole mechanism forcing changes in the mineral assemblages, and/or that each mineral assemblage adjusted (equilibrated) to climatic change on a different time scale.

Scores for each factor were examined by spectral analysis, and peaks at or near the primary Milankovitch frequencies occur for all factors. Factors 1, 2, and 4 each exhibit significant coherence and a zero phase relationship at a single Milankovitch frequency with the Site 722 eolian MAR record (Factor 1 at 23 k.y., Factor 2 at 41 k.y., Factor 4 at 100 k.y.). These coherence and zero phase relationships are consistent with the interpretation of the eolian MAR record and the scores for Factors 1,2 , and 4 as indicators of glacially forced aridity caused by changes in solar insolation. The physical processes that produce coherence in a single Milankovitch frequency for each factor are not known at this time; working hypotheses include: (1) preferential development of the different mineral assemblages by weathering over varying time scales, as controlled by the mineral stabilities; and (2) preferential development of suitable continental source environments over varying time scales of climatic change.

\section{ACKNOWLEDGMENTS}

We are grateful to the officers and crew of the SEDCO BP 471 and the ODP technical staff for their efforts during Leg 117 , and to A. Singer and F. Sirocko for helpful reviews of this manuscript. Timothy Horner assisted with sample preparation. This research was supported by Joint Oceanographic Institu- 


\section{Maximum eccentricity}

(100 kyr)
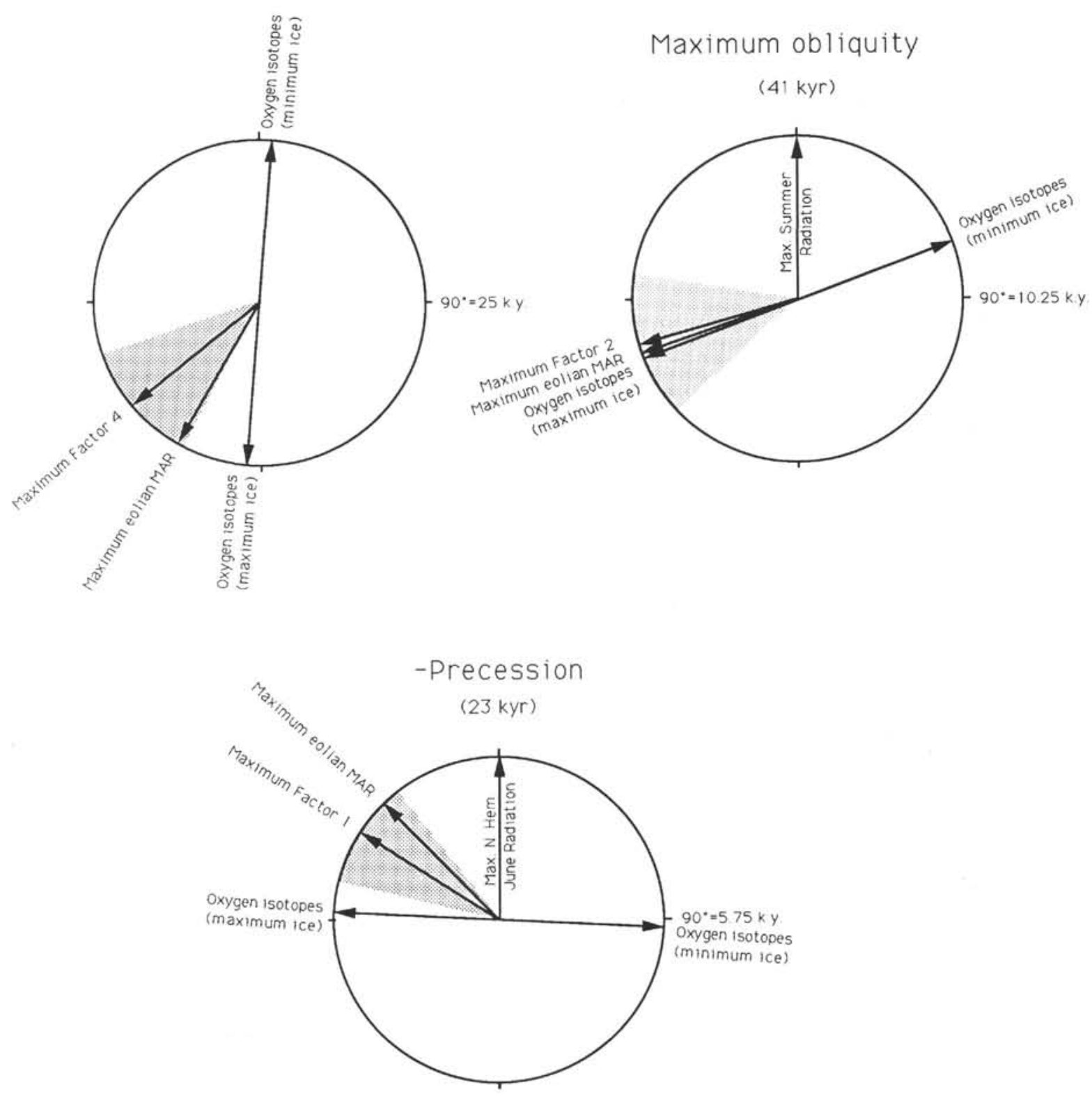

Figure 5. Phase wheel summaries of climatic indices at Site 722. Each wheel presents phase relationships between climatic indices and insolation variations in a specific primary Milankovitch frequency. Zero phase is located at the top of the circle. The phase difference between the beginning of the insolation cycle and the given climatic record is plotted as a vector whose angle is measured clockwise (+, lagging) or counterclockwise (-, leading) from the zero point. The shaded area centered on the factor vector is the error associated with the phase estimate for each factor. In each case, the maximum eolian MAR is within the error band of the factor phase estimate, indicating that the two climatic indices (factor scores and eolian MAR) have zero phase difference. Maximum aridity occurs during maxima in eolian MAR and factor scores, and occurs at or after maximum ice volume in each frequency band.

tions-United States Science Advisory Committee subgrants to L. Krissek and to S. Clemens and W. Prell; this work was performed while S. Clemens held a JOI/USSAC Ocean Drilling Fellowship.

\section{REFERENCES}

Blatt, H., Middleton, G. V., and Murray, R., 1980. Origin of Sedimentary Rocks (2nd ed.): New Jersey (Prentice-Hall).
Brainpower, Inc., 1986. StatView 512+: Calabasas, CA (Brainpower, Inc.).

Chester, R., Sharples, E. J., and Sanders, G. S., 1985. The concentration of particulate aluminum and clay minerals in aerosols from the northern Arabian Sea. J. Sediment. Petrol., 55:37-41.

Clemens, S. C., and Prell, W. L., 1990. Late Pleistocene variability of Arabian Sea summer-monsoon winds and continental aridity: eolian records from the lithogenic component of deep-sea sediments. Paleoceanography, 5:109-145. 
COHMAP Members, 1988. Climatic changes of the last 18,000 years: observations and model simulations. Science, 241:1043-1052.

Davis, J. C., 1986. Statistics and Data Analysis in Geology (2nd ed.): New York (Wiley).

Dixon, J. B., and Weed, S. B., 1977. Minerals in Soil Environments; Madison, WI (Soil Sci. Soc. of Am.).

Gibbs, R. J., 1967. Quantitative X-ray diffraction analysis using clay mineral standards extracted from the samples to be analyzed. Clay Min., 7:79-90.

Griffin, J., Windom, H., and Goldberg, E. D., 1968. The distribution of clay minerals in the world ocean. Deep-Sea Res., 15:433-459.

Imbrie, J., Hays, J. D., Martinson, D. G., McIntyre, A., Mix, A. C., Morley, J. J., Pisias, N. G., Prell, W. L., and Shackleton, N. J., 1984. The orbital theory of Pleistocene climate: support from a revised chronology of the marine oxygen isotopic record. In Berger, A., Imbrie, J., Hays, J., Kukla, G., and Saltzman, B. (Eds.), Milankovitch and Climate (Pt. 1): Dordrecht (D. Reidel), 269-305.

Imbrie, J., McIntyre, A., and Mix, A., in press. Oceanic response to orbital forcing in the Late Quaternary: observational and experimental strategies. In Duplessy, J. C., et al. (Eds.), Climate and Geosciences: Boston (D. Reidel).

Jenkins, G. M., and Watts, D. G., 1968. Spectral Analysis and Its Applications: San Francisco (Holden Day).

Kolla, V., Henderson, L., Biscaye, P. E., 1976. Clay mineralogy and sedimentation in the western Indian ocean. Deep-Sea Res. Oceanogr. Abstr., 23:949-961.

Kolla, V., Kostecki, J. A., Robinson, F., Biscaye, P. E., and Ray, P. K., 1981. Distribution and origins of clay minerals and quartz in surface sediments of the Arabian Sea. J. Sediment. Petrol., 51:563-569.

Krissek, L. A., 1982. Sources, dispersal, and contributions of finegrained terrigenous sediments on the Oregon and Washington continental slope [Ph.D. dissert.]. Oregon State Univ., Corvallis. 1989. Bulk mineralogy of nonbiogenic sediments from ODP Sites 642 and 643, Norwegian Sea: implications for sediment provenance and recycling. In Eldholm, O., Thiede, J., Taylor, E., et al., Proc. ODP, Sci. Results, 104: College Station, TX (Ocean Drilling Program), 29-39.

Kutzbach, J. E., 1981. Monsoon climate of the early Holocene: climate experiment with the earth's orbital parameters for 9000 years ago. Science, 214:59-61.

Kutzbach, J. E., and Otto-Bliesner, B. L., 1982. The sensitivity of the African-Asian monsoonal climate to orbital parameter changes for 9000 years B.P. in a low-resolution General Circulation Model. $J$. Atmos. Sci., 39:1177-1188.

Lisitzin, A. P., 1972. Sedimentation in the World Ocean, with Emphasis on the Nature, Distribution and Behavior of Marine Suspensions. Soc. Econ. Paleontol. Mineral. Spec. Publ., 17.

Nair, R. R., Ittekkot, V., Manganini, S. J., Ramaswamy, V., Haake, B., Degens, E. T., Desai, B. N., and Honjo, S., 1989. Increased particle flux to the deep ocean related to monsoons. Nature, 338:749-751.
Prell, W. L., 1984. Monsoonal climate of the Arabian Sea during the late Quaternary: a response to changing solar radiation. In Berger, A. L., Imbrie, J., Hays, J., Kukla, G., and Saltzman, B. (Eds.). Milankovitch and Climate (Pt. 1): Dordrecht (D. Reidel), 349-366.

Prell, W. L., and Curry, W. B., 1981. Faunal and isotopic indices of monsoonal upwelling: western Arabian Sea. Oceanol. Acta, 4:9198.

Prell, W. L., Nuitsuma, N., et al., 1989. Proc. ODP, Init. Repts., 117: College Station, TX (Ocean Drilling Program).

Prell, W. L., and van Campo, E., 1986. Coherent response of Arabian Sea upwelling and pollen transport to late Quaternary monsoonal winds. Nature, 323:526-528.

Savoie, D. L., Prospero, J. M., and Nees, R. T., 1987. Nitrate, non-seasalt sulfate, and mineral aerosol over the northwestern Indian Ocean. J. Geophys. Res., 92:933-942.

Scheidegger, K. F., and Krissek, L. A., 1982. Dispersal and deposition of eolian and fluvial sediments off Peru and northern Chile. Geol. Soc. Am. Bull., 93:150-162.

Shipboard Scientific Party, 1989. Site 722. In Prell, W. L., Niitsuma, N., et al., Proc. ODP, Init. Repts., 117: College Station, TX (Ocean Drilling Program), 255-318.

Sirocko, F., and Sarnthein, M., 1989. Wind-borne deposits in the northwest Indian Ocean: record of Holocene sediments versus modern satellite data. In Leinen, M., and Sarnthein, M. (Eds.), Paleoclimatology and Paleometeorology: Modern and Past Patterns of Global Atmospheric Transport. NATO ASI Ser., 282:401-433.

Street, F. A., and Grove, A. T., 1979. Global maps of lake-level fluctuations since 30,000 yr B.P. Quat. Res., 12:83-118.

Ugolini, F. C., 1986. Processes and rates of weathering in cold and polar environments. In Colman, S. M., and Dethier, D. P. (Eds.), Rates of Chemical Weathering of Rocks and Minerals: Orlando, FL (Academic Press), 193-235.

van Campo, E., 1986. Monsoon fluctuations in two 20,000-yr B.P. oxygen-isotope/pollen records off southwest India. Quat. Res., 26:376388.

van Campo, E., Duplessy, J. C., and Rossignol-Strick, M., 1982. Climatic conditions deduced from a 150-k.y. oxygen isotope-pollen record from the Arabian Sea. Nature, 296:56-59.

Velde, B., 1985. Clay Minerals: A Physico-Chemical Explanation of Their Occurrence: Amsterdam (Elsevier).

Webster, P. J., 1987. The elementary monsoon. In Fein, J. S., and Stephens, P. L. (Eds.), Monsoons: New York (Wiley), 3-32.

Date of initial receipt: 2 October 1989

Date of acceptance: 20 July 1990

Ms 117B-183 
APPENDIX

Data for Samples from Hole 722B

\begin{tabular}{|c|c|c|c|c|c|c|c|c|c|c|c|c|c|c|}
\hline Dpth & Age & $\mathrm{Sm}$ & Plyg & II & Qtz & Plg & Kaol & Chl & Calc & Dol & F1 & F2 & F3 & F4 \\
\hline 0004 & 006.4 & 0.766 & 0.359 & 0.266 & 0.797 & 0.172 & 0.250 & 0.313 & 1.766 & 1.203 & -1.991 & -0.571 & 1.011 & -0.108 \\
\hline 0024 & 008.7 & 0.778 & 0.254 & 0.317 & 1.810 & 0.317 & 0.397 & 0.397 & 0.587 & 3.444 & -0.739 & -0.342 & 0.794 & -0.484 \\
\hline 0044 & 011.1 & 0.766 & 0.511 & 1.723 & 3.702 & 1.723 & 0.489 & 1.383 & 0.000 & 7.255 & 2.266 & 3.125 & -1.914 & -0.149 \\
\hline 0064 & 013.4 & 1.217 & 0.717 & 0.587 & 1.152 & 0.000 & 0.000 & 0.000 & 0.000 & 5.239 & -2.478 & -2.218 & 1.585 & 3.296 \\
\hline 0084 & 015.8 & 0.555 & 0.455 & 0.273 & 0.955 & 0.618 & 0.000 & 0.982 & 0.500 & 3.773 & -0.145 & -1.094 & -1.159 & 0.904 \\
\hline 0104 & 018.4 & 0.373 & 0.271 & 0.424 & 1.237 & 0.263 & 0.169 & 0.551 & 0.000 & 3.271 & -0.600 & -0.762 & -0.527 & 0.043 \\
\hline 0124 & 022.5 & 0.613 & 0.570 & 0.344 & 1.957 & 0.839 & 0.237 & 1.333 & 0.495 & 5.097 & 0.816 & -0.541 & -1.326 & 1.077 \\
\hline 0144 & 026.6 & 0.646 & 0.202 & 0.414 & 1.535 & 0.687 & 0.434 & 0.374 & 0.980 & 3.667 & -0.896 & 0.767 & -0.154 & -0.685 \\
\hline 0164 & 030.7 & 0.808 & 0.260 & 0.356 & 1.173 & 0.615 & 0.212 & 0.952 & 0.279 & 4.317 & 0.118 & -0.392 & -0.124 & -0.404 \\
\hline 0184 & 034.8 & 0.311 & 0.408 & 0.485 & 1.757 & 0.427 & 0.204 & 0.806 & 0.184 & 4.796 & 0.077 & -0.795 & -1.237 & 0.903 \\
\hline 0204 & 038.9 & 1.067 & 0.260 & 0.356 & 1.606 & 0.510 & 0.135 & 1.048 & 0.385 & 3.606 & 0.705 & -0.935 & 0.821 & -0.955 \\
\hline 0224 & 043.0 & 1.121 & 0.252 & 1.701 & 1.645 & 0.514 & 0.495 & 0.832 & 0.290 & 3.664 & -0.400 & 2.108 & 1.725 & -1.583 \\
\hline 0244 & 047.2 & 0.405 & 0.091 & 0.380 & 1.058 & 0.488 & 0.116 & 1.008 & 0.504 & 2.694 & 0.594 & -0.407 & -0.780 & -1.537 \\
\hline 0264 & 051.3 & 0.414 & 0.515 & 0.364 & 1.606 & 0.354 & 0.000 & 0.7 & 0.000 & 3.495 & -0.196 & -1.571 & -0.965 & 1.295 \\
\hline 0284 & 055.4 & 0.821 & 0.690 & 0.000 & 0.512 & 0.631 & 0.357 & 0.786 & 0.298 & 4.0 & -2 & -0.5 & -0 . & 2.257 \\
\hline 0304 & 059.5 & 0.509 & 0.436 & 0.527 & 2.018 & 0.491 & 0.418 & 1.145 & 0.000 & 6.055 & 0.580 & -0.412 & -0 & 0.794 \\
\hline 0324 & 063.6 & 0.315 & 0.339 & 0.363 & 1.339 & 0.387 & 0.242 & 0.532 & 0.000 & 3.742 & -0.768 & -0.517 & -0.936 & 0.531 \\
\hline 0344 & 068.9 & 0.363 & 0.235 & 0.186 & 1.598 & 0.696 & 0.667 & 0.382 & 0.000 & 0.353 & -1.520 & 1.692 & -0.263 & -1.606 \\
\hline 0364 & 074.9 & 0.500 & 0.420 & 0.850 & 1.550 & 0.580 & 0.210 & 0.620 & 0.000 & 4.360 & -0.569 & 0.177 & -0.814 & 0.728 \\
\hline 0384 & 081.4 & 0.261 & 0.000 & 0.559 & 1.369 & 0.396 & 0.135 & 0.640 & 0.000 & 2.766 & 0.736 & -0.153 & -0.811 & -1.749 \\
\hline 0404 & 090.9 & 0.234 & 0.234 & 0.448 & 1.269 & 0.5 & 0.1 & 0.862 & 0.1 & 2.5 & 0.070 & -0.014 & -1.350 & -0.719 \\
\hline 0424 & 100.4 & 0.413 & 0.500 & 0.942 & 1.288 & 0.442 & 0.606 & 0.981 & 0.067 & 2.163 & -1.2 & & -0.163 & -0.060 \\
\hline 0444 & 109.6 & 0.515 & 0.399 & 0.607 & 1.037 & 0.503 & 0.221 & 0.601 & 0.000 & 0.172 & -1.355 & 0.52 & -0 . & -0.600 \\
\hline 0464 & 118.8 & 0.735 & 0.633 & 0.873 & 1.466 & 0.615 & 0.508 & & 0.0 & 3.2 & -1.041 & 0.861 & & 0.377 \\
\hline 0484 & 124.0 & 0.656 & 0.440 & 0.456 & 1.456 & 0.440 & 0.272 & 0.792 & 0.0 & 3.3 & -0. & -0.404 & -0 . & 0.394 \\
\hline 0504 & 127.2 & 0.901 & 0.535 & 0.634 & 1.762 & 0.871 & 0.584 & 0.950 & 0.000 & 5.3 & -0.602 & 1.066 & -0 . & 0.780 \\
\hline 0524 & 130.3 & 0.444 & 0.556 & 0.778 & 1.667 & 0.657 & 0.157 & 0.889 & 0.194 & 5.898 & -0.065 & -0.377 & -1.532 & 1.840 \\
\hline 0558 & 135.7 & 0.802 & 0.510 & 0.698 & 1.333 & 0.490 & 0.490 & 0.594 & 0.375 & 4.688 & -1.507 & 0.491 & 0.321 & 1.089 \\
\hline 0574 & 138.5 & 0.912 & 0.794 & 0.804 & 1.627 & 0.461 & 0.275 & 0.647 & 0.000 & 5.333 & -1.457 & -0.505 & 0.190 & 2.828 \\
\hline 0594 & 142.0 & 0.804 & 0.559 & 0.588 & 2.020 & 0.735 & 0.529 & 0.990 & 0.000 & 6.245 & -0 . & 0.351 & -0.339 & 1.279 \\
\hline 0614 & 145.4 & 0.906 & 0.576 & 1.271 & 2.271 & 0.78 & 0.882 & 1.000 & 1.8 & 4.965 & -0.786 & 2.5 & 0.615 & 0.242 \\
\hline 0634 & 148.9 & 0.702 & 0.238 & 0.646 & 1.991 & 0.685 & 0.461 & 0.919 & 0.000 & 5.891 & 0.527 & 0.4 & -0.319 & -0.442 \\
\hline 0674 & 155.9 & 0.844 & 0.494 & 0.896 & 2.519 & 0.481 & 0.857 & 1.273 & 0.000 & 6.208 & 0.3 & & 0.698 & 0.202 \\
\hline 0694 & 159.3 & 0.474 & 0.350 & 0.343 & 1.248 & 0.62 & 0.255 & 0.839 & 0.1 & 3.394 & -0.355 & -0 . & -0 & 0.046 \\
\hline 0714 & 162.8 & 0.697 & 0.393 & 0.787 & 2.404 & 0.528 & 0.000 & 1.180 & 1.7 & 7.3 & & & -0 & 0.944 \\
\hline 0734 & 166.3 & 0.759 & 0.034 & 0.871 & 1.543 & 0.319 & 0.293 & 1.388 & 0.897 & 4.19 & 1.56 & -0.0 & & -2.293 \\
\hline 0754 & 169.8 & 0.728 & 0.395 & 0.474 & 1.316 & 0.351 & 0.000 & 0.842 & 0.8 & 3.8 & -0.0 & -1.401 & -0.084 & 0.496 \\
\hline 0774 & 174.1 & 0.632 & 0.195 & 0.391 & 1.621 & 0.954 & 0.425 & 0.425 & 3.506 & 6.356 & -0.437 & 0.792 & -1.067 & 0.090 \\
\hline 0794 & 178.9 & 1.075 & 0.208 & 0.858 & 1.821 & 0.604 & 0.179 & 1.113 & 0.226 & 6.472 & 1.261 & -0.384 & 0.465 & -0.601 \\
\hline 0814 & 184.3 & 0.865 & 0.253 & 0.653 & 1.880 & 0.511 & 0.435 & 1.100 & 0.320 & 3.700 & 0.547 & 0.335 & 0.678 & -1.286 \\
\hline 0854 & 202.0 & 0.554 & 0.336 & 0.556 & 1.856 & 0.615 & 0.299 & 0.663 & 3.112 & 3.013 & -0.249 & 0.259 & -0.411 & -0.366 \\
\hline 0874 & 210.9 & 0.753 & 0.155 & 0.722 & 1.866 & 0.887 & 0.237 & 1.124 & 0.206 & 3.433 & 1.180 & 0.735 & -0.376 & -1.859 \\
\hline 0894 & 219.0 & 0.298 & 0.553 & 0.660 & 1.415 & 1.106 & 0.330 & 1.085 & 1.021 & 2.628 & -0.409 & 1.421 & -2.099 & 0.433 \\
\hline 0914 & 222.9 & 0.525 & 0.258 & 0.592 & 1.758 & 0.517 & 0.342 & 0.700 & 0.000 & 3.742 & -0.098 & 0.210 & -0.3 & -0.536 \\
\hline 0934 & 226.8 & 0.890 & 0.418 & 0.385 & 1.912 & 1.055 & 0.352 & 0.769 & 0.923 & 4.560 & -0.140 & 0.621 & -0 & 0.161 \\
\hline 0954 & 230.7 & 0.486 & 0.305 & 0.686 & 1.762 & 0.657 & 0.124 & 0.629 & 0.248 & 2.790 & -0.040 & 0.117 & -0.785 & -0.432 \\
\hline 0974 & 234.7 & 0.539 & 0.344 & 0.484 & 1.344 & 0.398 & 0.391 & 0.500 & 0.969 & 2.344 & -1.243 & 0.292 & 0.073 & -0.226 \\
\hline 0994 & 238.5 & 0.897 & 0.495 & 0.664 & 1.542 & 0.449 & 0.215 & 0.776 & 1.327 & 2.570 & -0.674 & -0.258 & 0.658 & 0.216 \\
\hline 1014 & 242.2 & 0.593 & 0.165 & 0.352 & 2.132 & 0.407 & 0.000 & 0.637 & 0.549 & 4.275 & 0.977 & -1.482 & -0.375 & -0.592 \\
\hline 1034 & 245.9 & 0.753 & 0.309 & 0.679 & 2.753 & 0.901 & 0.222 & 1.444 & 0.630 & 6.148 & 2.430 & -0.230 & -0.903 & -0.571 \\
\hline 1054 & 249.5 & 0.926 & 0.639 & 0.519 & 1.981 & 1.009 & 0.231 & 1.222 & 2.065 & 3.306 & 0.284 & 0.212 & -0.473 & 0.588 \\
\hline 1074 & 252.8 & 0.299 & 0.368 & 1.057 & 2.437 & 1.172 & 0.586 & 1.414 & 0.609 & 5.483 & 1.317 & 2.201 & -2.085 & -0.542 \\
\hline 1094 & 256.2 & 1.138 & 0.613 & 0.650 & 2.100 & 0.550 & 0.425 & 1.350 & 1.275 & 7.450 & 0.618 & -0.689 & 0.522 & 1.565 \\
\hline 1114 & 259.5 & 0.732 & 0.659 & 0.805 & 1.634 & 0.976 & 0.159 & 0.951 & 0.366 & 3.829 & -0.411 & 0.465 & -1.045 & 1.326 \\
\hline 1134 & 262.8 & 1.108 & 0.360 & 0.757 & 1.477 & 0.955 & 0.369 & 1.099 & 0.333 & 3.378 & 0.019 & 1.195 & 0. & -0.976 \\
\hline 1154 & 266.2 & 0.954 & 0.425 & 0.954 & 1.747 & 0.678 & 0.253 & 0.828 & 1.080 & 3.494 & -0.227 & 0.553 & & -0.202 \\
\hline 1174 & 270.3 & 1.323 & 0.581 & 0.887 & 2.952 & 1.565 & 0.532 & 1.274 & 0.323 & 6.000 & 1.063 & 1.996 & -0.178 & 0.041 \\
\hline 1194 & 279.3 & 0.579 & 0.446 & 0.471 & 0.306 & 0.851 & 0.248 & 0.579 & 0.174 & 3.967 & -1.842 & 0.673 & -1.187 & 1.112 \\
\hline 1214 & 287.9 & 1.754 & 0.579 & 0.877 & 1.158 & 0.982 & 0.456 & 1.281 & 4.965 & 3.018 & -0.731 & 1.444 & 2.181 & -0.506 \\
\hline 1234 & 293.9 & 0.505 & 0.138 & 0.303 & 1.789 & 0.670 & 0.248 & 0.761 & 0.642 & 2.624 & 0.455 & 0.070 & -0.590 & -1.529 \\
\hline 1254 & 300.2 & 0.696 & 0.506 & 0.987 & 0.899 & 1.443 & 0.291 & 1.165 & 2.165 & 4.342 & -0.440 & 2.239 & -1.835 & 0.408 \\
\hline 1274 & 308.2 & 0.474 & 0.377 & 0.475 & 1.262 & 0.607 & 0.164 & 0.852 & 2.098 & 1.508 & -0.448 & -0.041 & 0.362 & -0.713 \\
\hline 1294 & 316.2 & 0.640 & 0.280 & 0.440 & 1.860 & 0.920 & 0.000 & 1.720 & 0.820 & 2.740 & 2.354 & -0.459 & -1.157 & -1.557 \\
\hline 1314 & 324.2 & 0.968 & 0.194 & 0.823 & & 0.6 & 0.3 & 0.758 & 1.839 & 2.387 & -0.260 & 1.012 & 0.968 & -1.777 \\
\hline 1334 & 331.4 & 1.000 & 0.309 & 0.364 & 1.327 & 0.436 & 0.000 & 0.927 & 0.636 & 1.8 & 0.199 & -1.111 & 0.832 & -0.925 \\
\hline 1354 & 334.3 & 0.906 & 0.377 & 0.604 & 1.604 & 0.887 & 0.245 & 1.038 & 0.585 & 2.830 & & & -0.044 & -0.748 \\
\hline 1374 & 337.1 & 1.627 & 0.196 & 0.804 & 1.824 & 0.373 & 0.196 & 0.608 & 1.569 & 3.941 & & -0.443 & 2.862 & -1.430 \\
\hline 1394 & 340.0 & 0.607 & 0.262 & 0.525 & 2.066 & 0.656 & 0.279 & 0.672 & 1.934 & 4.787 & 0.318 & -0.056 & -0.565 & -0.249 \\
\hline 1414 & 343.9 & 0.807 & 0.312 & 0.507 & 1.692 & 0.680 & 0.232 & 0.690 & 0.000 & 3.944 & -0.110 & -0.030 & -0.058 & -0.272 \\
\hline 1434 & 348.5 & 0.781 & 0.425 & 0.438 & 1.055 & 0.205 & 0.096 & 0.589 & 0.000 & 2.918 & -1.028 & -1.199 & 0.541 & 0.587 \\
\hline 1454 & 353.0 & 0.611 & 0.370 & 0.593 & 1.722 & 0.500 & 0.000 & 0.889 & 0.000 & 3.352 & 0.477 & -0.940 & -0.510 & 0.018 \\
\hline 1474 & 357.5 & 0.527 & 0.273 & 0.473 & 2.364 & 0.345 & 0.564 & 0.727 & 0.000 & 2.873 & -0.007 & 0.310 & 0.355 & -1.052 \\
\hline 1514 & 366.6 & 0.862 & 0.646 & 0.308 & 1.138 & 0.369 & 0.000 & 1.031 & 0.000 & 2.631 & -0.528 & -1.654 & 0.174 & 1.330 \\
\hline 1534 & 371.1 & 1.000 & 0.426 & 0.936 & & & & & 0.000 & 3.362 & -0.345 & -0.017 & 1.210 & -0.217 \\
\hline 1554 & 375.9 & 0.781 & 0.266 & 0.703 & 1.203 & 0.406 & 0.359 & 0.859 & 0.781 & 3.047 & -0.454 & 0.345 & 0.614 & -0.894 \\
\hline 1574 & 381.9 & 1.038 & 0.635 & 0.923 & 2.250 & 0.750 & 0.365 & 1.058 & 1.500 & 2.385 & -0.160 & 0.767 & 0.724 & 0.062 \\
\hline 1594 & 387.9 & 0.645 & 0.306 & 0.726 & 1.516 & 0.403 & 0.323 & 1.032 & 3.226 & 2.581 & 0.075 & 0.193 & 0.255 & -0.958 \\
\hline
\end{tabular}


Appendix (continued).

\begin{tabular}{|c|c|c|c|c|c|c|c|c|c|c|c|c|c|c|}
\hline Dpth & Age & $\mathrm{Sm}$ & Plyg & II & Qtz & $\mathrm{Plg}$ & Kaol & Chl & Calc & Dol & F1 & F2 & F3 & F4 \\
\hline 1614 & 393.9 & 1.034 & 0.241 & 0.345 & 1.759 & 0.707 & 0.345 & 1.069 & 0.638 & 3.293 & 0.565 & 0.095 & 0.698 & -1.438 \\
\hline 1634 & 399.9 & 0.850 & 0.237 & 0.395 & 1.191 & 0.467 & 0.375 & 0.768 & 2.075 & 2.421 & -0.610 & 0.211 & 0.772 & -1.170 \\
\hline 1654 & 407.7 & 1.071 & 0.357 & 0.357 & 1.548 & 0.643 & 0.476 & 0.476 & 4.524 & 4.643 & -1.117 & 0.314 & 0.856 & 0.138 \\
\hline 1674 & 423.5 & 0.897 & 0.621 & 0.62 & 2.000 & 0.448 & 0.37 & 0.724 & 8.6 & 5.6 & -0.694 & -0.510 & 0.341 & 1.775 \\
\hline 1694 & 427.2 & 0.824 & 0.765 & 0.88 & 1.765 & 0.559 & 0.912 & 1.029 & 1.794 & 6.029 & -1.574 & 1.485 & 0.375 & 2.041 \\
\hline 1714 & 430.9 & 0.960 & 0.440 & 0.480 & 1.540 & 1.020 & 0.360 & 0.800 & 0.000 & 4.440 & -0.512 & 0.789 & -0.274 & 0.258 \\
\hline 1734 & 434.7 & 0.688 & 0.563 & 1.000 & 2.281 & 1.188 & 0.781 & 0.625 & 0.000 & 5.813 & -1.091 & 2.370 & -0.898 & 0.965 \\
\hline 1754 & 439.2 & 0.879 & 0.414 & 0.466 & 1.552 & 0.362 & 0.172 & 0.517 & 2.121 & 4.672 & -0.678 & -1.020 & 0.443 & 0.860 \\
\hline 1774 & 443.7 & 1.037 & 0.630 & 0.796 & 1.963 & 0.481 & 0.000 & 0.593 & 1.870 & 5.259 & -0.408 & -1.260 & 0.356 & 1.952 \\
\hline 1794 & 448.2 & 0.564 & 0.145 & 0.345 & 1.200 & 0.455 & 0.000 & 0.655 & 1.491 & 5.291 & 0.331 & -1.279 & -0.779 & -0.060 \\
\hline 1814 & 452.7 & 0.971 & 0.629 & 0.686 & 3.029 & 0.743 & 0.000 & 1.029 & 0.000 & 8.286 & 1.634 & -1.780 & -0.718 & 2.306 \\
\hline 1834 & 457.2 & 0.333 & 0.667 & 0.600 & 4.000 & 0.000 & 0.000 & 1.633 & 0.833 & 5.133 & 3.248 & -3.237 & -0.783 & 1.3316 \\
\hline 1854 & 461.7 & 1.059 & 0.412 & 0.529 & 4.500 & 0.529 & 0.000 & 2.000 & 1.000 & 5.824 & 5.025 & -2.611 & 0.353 & -0.987 \\
\hline 1874 & 466.7 & 1.722 & 0.833 & 0.944 & 3.000 & & & & & & -0.2 & & 3.1 & 0.766 \\
\hline 1894 & 472.0 & 0.560 & 0.400 & 0.520 & 2.500 & 0.320 & 0.440 & 2.080 & 2.200 & 3.040 & 2.497 & -0.643 & 0.03 & -1.404 \\
\hline 1914 & 478.7 & 1.481 & 0.259 & 0.296 & 1.963 & 0.519 & 0.000 & 0.926 & 0.481 & 4.259 & 1.038 & -1.6663 & 1.740 & -0.899 \\
\hline 1934 & 485.3 & 0.525 & 0.150 & 0.200 & 1.175 & 0.400 & 0.225 & 0.575 & 0.650 & 3.125 & -0.398 & -0.548 & -0.240 & -0.805 \\
\hline 1954 & 492.6 & 0.400 & 0.100 & 0.200 & 0.933 & 0.183 & 0.200 & 0.417 & 0.117 & 2.933 & -0.760 & -0.842 & -0.179 & -0.763 \\
\hline 1974 & 503.7 & 0.714 & 0.286 & 0.286 & 0.743 & 0.571 & 0.000 & 0.743 & 0.571 & 2.886 & -0.455 & -0.803 & -0.370 & -0.181 \\
\hline 1994 & 513.7 & 2.040 & 0.200 & 0.480 & 3.320 & 0.440 & 0.440 & 1.000 & 0.000 & 3.000 & 1.566 & -0.531 & 4.306 & -2.930 \\
\hline 2014 & 518.1 & 0.389 & 0.333 & 0.333 & 1.111 & 0.444 & 0.389 & 0.611 & 0.000 & 2.389 & -1.173 & 0.230 & -0.500 & -0.148 \\
\hline 2034 & 522.5 & 1.556 & 0.778 & 1.000 & 3.000 & 0.444 & 0.444 & 1.778 & 6.444 & 10.556 & 1.917 & -1.438 & 1.390 & 2.549 \\
\hline
\end{tabular}

Notes: "Dpth" is ODP depth for each sample in cm below seafloor; "Age" is in ka; "Sm," "Plyg," "Il," "Qtz," "Plg," "Kaol," "Chl," "Calc," and "Dol" are mineral/boehmite peak area ratios for smectite, palygorskite, illite, quartz, plagioclase feldspar, kaolinite, chlorite, calcite, and dolomite, respectively. "F1," "F2," "F3," and "F4" are scores for each sample for Factor 1, Factor 2, Factor 3, and Factor 4, respectively. 